\title{
Türkiye Finansal Raporlama Standardı 16: Kiralamalar Standardının Borsa İstanbul Şirketlerinin Finansal Tablolarına Etkisi Üzerine Bir Araştırma
}

\author{
A Study on the Effect of International Financial Reporting Standards 16: \\ Leases Standard on the Financial Statements of Borsa Istanbul Companies
}

\author{
Berke $\operatorname{Koç}^{1}$ (1) \\ ${ }^{1}$ Arş. Gör., Kırklareli Üniversitesi, Uygulamalı Bilimler Fakültesi, Muhasebe ve Finans Yönetimi Anabilim Dalı, Kırklareli, Türkiye \\ E-posta: berkekoc@klu.edu.tr \\ ORCID: B.K. 0000-0003-4889-3816
}

\section{ÖZ}

Muhasebe standartlarını düzenleyen kurullar, şirketlerin mali bilgilerini gerçeğe uygun, anlaşılabilir ve şeffaf bir şekilde sunabilmesine yol göstermek amacıyla UFRS standardını yayınlamıştır. UFRS standardının ele aldığı konulardan biri de kiralama işlemleridir. Kiralama işlemleri, söz konusu standartta "UFRS 16 Kiralamalar" bölümünde açıklanmıştır.

Bu çalışmada, BİST 100 endeksinde faaliyet gösteren finansal kuruluşlar ve holdingler dışında kalan şirketlerin TFRS 16 standardının uygulanmasından önceki iki yıl ve TFRS 16 standardının uygulanmasından sonraki iki yıla ait finansal tabloları incelenmiştir. incelenmiş ve finansal kiralama işlemlerinden etkilenen finansal tablo kalemleri ile şirketlerin finansal oranları sunulmuştur.. Böylece yeni kiralama standardının finansal tablolar ve finansal oranlar üzerindeki etkisini görmek mümkün olmuştur.

Yapılan analizler sonucunda başlıca finansal tablo kalemlerinin tümünde artış tespit edilmiştir. Ayrıca aktif kârlılık ve net kâr marjı oranlarında azalış; toplam borç / toplam varlıklar ve faaliyet kâr marjı oranlarında artış saptanmıştır.

Anahtar kelimeler: Finansal Kiralama, Faaliyet Kiralamas1, TFRS 16

\section{ABSTRACT}

The boards that regulate accounting paradigms have published the IFRS standard to guide companies in presenting their financial information honestly, explicably, and transparently. One issue that the IFRS standard deals with is leasing transactions, which are explained in the "IFRS 16 Leases" section of the relevant standard.

This study examines the financial statements of the companies operating in the BIST 100 index, excluding financial institutions and holdings, for the two years before and years after the implementation of the TFRS 16 standard. The study then presents the financial statement items affected by the leasing transactions and the companies' financial ratios, thus showing the effect of the new leasing standard on the financial statements and ratios. As a result of the analyses, increases were determined in all of the main financial statement items. In addition to decrease in asset profitability and net profit margin ratios, an increase was observed in the ratios of total debt/total assets and operating profit margin.

Keywords: Financial Lease, Operational Lease, IFRS 16

Başvuru/Submitted: 03.10.2021 Revizyon Talebi/Revision Requested: 10.11.2021 Son Revizyon/Last Revision Received: 07.12.2021 Kabul/Accepted: 27.12.2021 Sorumlu yazar/Corresponding author: Berke Koç / berkekoc@klu.edu.tr

Atıf/Citation: Koc, B. (2022). Türkiye finansal raporlama standardı 16: Kiralamalar standardının borsa İstanbul şirketlerinin finansal tablolarına etkisi üzerine bir araştırma. Muhasebe Enstitüsü Dergisi - Journal of Accounting Institute, 66, 113-136. https://doi.org/10.26650/MED.1004034 


\section{Extended Abstract}

Today, an essential condition for businesses to gain competitive advantage is to adapt to the constantly developing technology. It is necessary to make continuous investments to ensure the said harmony and catch up with the speed of technology, which raises the problem of financing. Although leasing transactions do not have a long history, their importance is increasing daily, and they are an alternative financing technique used to eliminate this problem.

The increasing importance of this alternative financing technique has revealed the situation of accounting for leasing transactions. The International Accounting Standards Board published IAS 17 in this context, which many countries criticized. As a result, the International Accounting Standards Board prepared the IFRS 16 standard, translated into Turkish by the Public Oversight, Accounting, and Auditing Standards Authority and published as TFRS 16.

The IFRS 16 standard came into force on April 16, 2018 and was implemented in Turkey's accounting periods starting from December 31, 2018. Changes occurred in companies' financial statement items with the implementation, which also affected the financial ratios. In this context, this study aims to analyze the effect of the TFRS 16 standard on the financial statements and ratios of businesses and sectors in the BIST 100 index.

The research used financial data from companies in the BIST 100 index, excluding financial institutions and holdings. The remaining 65 companies, including their financial statements and footnotes for two years before and after the TFRS 16 transition, were examined to measure the standard's effect. The financial statements and footnotes for 2017, 2018, 2019, and 2020 were compared and analyzed in this context.

The research results indicated that the implementation of the TFRS 16 standard affected the sample companies by increasing period profit by $26.39 \%$, operating profit before financing expenses/incomes by $29.88 \%$, main operating profit by $30.53 \%$, interest expenses by $87.49 \%$, total assets by $57.12 \%$, and total liabilities by $59.64 \%$. Conversely, from $2017-2018$, when the companies applied the TAS 17 standard, and from 2019-2020, when the companies applied the TFRS 16 standard, decreases were found in the net profit margins and returns on assets ratios. An increase was observed in the companies' operating profit margin and total debt/total assets ratios.

When analyzing the effect of TFRS 16 on financial statements and financial ratios on a sectoral basis, the most significant change occurred in the Wholesale and Retail Trade, Hotel, and Restaurants sector. Conversely, when examining the financial statements and ratios of the companies operating in the manufacturing sector, which constitutes a large part of the companies in the sample, parallelism to the whole of the sample is detected.

With the TFRS 16 standard introduction, companies started to report assets and liabilities related to their assets subject to operating leases. Thus, financial statements are more transparent and understandable, and financial ratios have become more meaningful. In addition, this situation strengthened the fair presentation of the financial statements and ensured a better application of the "Full Disclosure Principle,"." 


\section{Giriş}

Kiralama; işletmelerin faaliyetlerini sürdürmek, büyümek ve rekabet avantajı sağlamak amacıyla elde edilmesi gereken fakat satın alınması oldukça güç varlıkları kullanabilmek için başvurdukları bir yöntemdir. Kiralama işlemleri, genel anlamda faaliyet kiralaması ve finansal kiralama olarak ikiye ayrılmakta olup; faaliyet kiralaması, kiralamaya konu varlığın mülkiyetinin kira süresi sonunda kiraya veren tarafta kaldığ1 ve risk ve getirilerin kiraya veren tarafa ait olduğu kısa süreli kiralama türü olarak tanımlanabilir (Şentürk, 2016: 623). Öte yandan finansal kiralama, kira konusu varlığın mülkiyetine sahip olmaktan doğan tüm risk ve getirilerin önemli ölçüde kiracı tarafa devredildiği bir finansman tekniği olarak belirtilebilir (TFRS 16, m.62). Şirketler, söz konusu finansman tekniği sayesinde ihtiyaç duydukları varlıkları, yüksek faizli banka kredilerini veya kendi öz kaynaklarını kullanmadan elde etmektedir. Bu sebeple finansal kiralama sektörü, çok uzak bir geçmişe sahip olmamasına karşın doğduğu andan itibaren hızla gelişmiş ve işletmeler için önemli bir finansman tekniği haline gelmiştir.

Kiralamanın geçmişi çok öncelere dayansa da günümüzdeki anlamıyla kiralama işlemleri, 1950'li yıllarda ABD'de ortaya çıkmıştır (Toroslu, 1998: 2). 1960 yılında İngiltere'de “The Merchantile Leasing Company" isimli finansal kiralama şirketinin kurulmasıyla birlikte kiralama işlemleri gelişmiş Avrupa ülkelerine yayılmıştır (Erol, 2011: 42). Kiralama işlemlerinin Türkiye'de resmen tanınması ve uygulanmaya başlanması ise 28/06/1985 yılında çıkan 3226 sayılı kanunla olmuştur (Ergül ve Dumanoğlu, 2003: 63-64).

Kiralama işlemlerinin muhasebeleştirilmesi ve raporlanması, yıllar boyunca tartışılan bir konu olarak literatürde yer almıştır. Bu tartışmaların son bulması amacıyla Uluslararası Muhasebe Standartları Kurulu ve Finansal Muhasebe Standartları Kurulu, 2006 yılında odak noktası uzun vadeli ve iptal edilmez olan kiralama işlemlerinin finansal durum tablosuda raporlanması olan bir proje başlatmış ve 2009 yılında bu çalışmayı sunmuştur. Çalışmaya yapılan yorumlar neticesinde 2010 yılında taslak metin yayınlanmış ve bu taslak metinde tüm kiralama işlemlerinin finansal durum tablosuda raporlanması gerektiği belirtilmiştir. Ancak sonrasında bu zorunluluk kaldırılmıştır. Yapılan çalışmalar sonucunda Uluslararas1 Finansal Raporlama Standard1 (UFRS - IFRS) 16, Uluslararası Muhasebe Standard1 (UMS - IAS) 17'nin yerine getirilmiş ve Ocak 2016'da yayımlanmıştır. Söz konusu standart, KGK tarafından birebir olarak Türkçe’ye çevrilmiş ve 16.4.2018 tarihli ve 29826 Sayılı Resmi Gazete'de yayımlanmıştır. Böylece söz konusu standart, 31.12 .2018 ve sonrasında başlayan hesap dönemlerinde uygulanmak üzere yürürlüğe girmiştir (Sarı ve Güngör, 2020: 288 - 289).

Söz konusu standardın uygulanmak üzere yürürlüğe girmesiyle birlikte kiracı taraflar, TFRS 16 standardının bir sonucu olarak kiralamaya konu olan varlığa ilişkin varlık ve yükümlülük kalemlerini finansal tablolarına yansıtmaya başlamıştır. Raporlamada meydana gelen söz konusu değişiklik; kiracı tarafların varlık, yükümlülük ve kar kalemleri gibi önemli finansal tablo kalemlerini etkilemiştir. Finansal tablo kalemlerinde gerçekleşen önemli değişimler, şirketlerin finansal tablolarının ve finansal oranlarının önemli ölçüde etkilenmesine sebep olmuştur. Bu bağlamda çalışmada yeni kiralama standardının borsanın genel durumunu yansıtacak öneme sahip BİST 100 endeksinde faaliyet gösteren şirketlerin finansal tablolarına ve finansal oranlarına etkisi analiz edilmeye çalışılmıştır.

Bu çalışma üç bölümden oluşmaktadır. Çalışmanın ilk bölümünde finansal kiralama kavramından ve finansal kiralama kavramıla faaliyet kiralaması kavramlarının farkından bahsedilecek, ikinci bölümünde ise yeni kiralama standardı TFRS 16 ele alınacaktır. Çalışmanın üçüncü bölümünde TFRS 16 standardının Borsa İstanbul (BİST)'da yer alan şirketlerin başlıca finansal tablo kalemlerine ve finansal oranlarına etkisi analiz edilecektir.

\section{Literatür İncelemesi}

Literatürde kiralama standardında meydana değişikliğin finansal tablolar ve finansal oranlar üzerindeki etkisini ele alan pek çok çalışma mevcuttur. Bu bağlamda literatürde yer alan çalışmalar ve söz konusu çalışmalarda ulaşılan sonuçlar şu şekilde sıralanabilir; 
Serçemeli ve Öztürk'ün 2016 yılında TFRS 16 standardının olası etkilerine ilişkin araştırmasında TFRS 16 standardının kullanılmaya başlanması ile varlık ve yükümlülük kalemlerinin daha gerçekçi bir sunumla şirketlerin finansal tablolarında yer alacağını ve söz konusu kiralama standardının etkisinin sektörel bazda değişeceği sonucuna ulaşılmıştır.

Öztürk'ün 2016 yılında gerçekleştirdiği çalışmada IFRS 16 ile IAS 17 standartları kıyaslanmış ve aynı zamanda yeni kiralama standardının Türkiye'de ve Almanya'da hisse senetleri halka açık olan hava yolu şirketlerinin finansal durumuna etkisi incelenmiştir. Çalışma sonucunda Öztürk, IFRS 16 standardının etkisinin sektörel bazda farklılık göstereceği ve kiralama türlerinden faaliyet kiralamasını sıkça uygulayan işletmelerin yeni standarttan daha fazla etkileneceği sonucuna ulaşmıştır.

Aktaş, Kargın ve Arııı, 2017 yılında kiralama işlemlerinin IFRS 16 standardına göre muhasebeleştirilmesi ve söz konusu standardın finansal tablolara ve oranlara etkisini analiz etmek amacıyla bir çalışma gerçekleştirmiştir. Yazarlar, kira tutarlarının bir hayli yüksek olduğu halka açık iki şirketin finansal tablolarını incelemiş ve şirketlerinin borçlanma oranlarının arttığını ve standardın etkisinin sektörel bazda değişiklik gösterdiğini saptamıştır.

Aslan, 2018 yılında kiracı taraf için kiralama işlemlerinin IFRS 16 standardına göre muhasebeleştirilmesi ve raporlanmasına ilişkin bir çalışma yapmıştır. Yazar, çalışma sonucunda hava yolu, toptan perakende ve telekomünikasyon sektörlerinde faaliyet gösteren şirketlerin diğer sektörlerde faaliyet gösteren şirketlere göre IFRS 16'dan daha fazla etkileneceği sonucuna ulaşmışırır.

Konuya ilişkin literatürde yer alan bir başka çalışma Marşap ve Yanık tarafından 2018 yılında gerçekleştirilmiştir. Yazarlar, çalışmalarında yeni kiralama standardına göre kiralama işlemlerinin muhasebeleştirilmesi ve raporlanması üzerinde durmuşlardır. Marşap ve Yanık, çalışma sonucunda kiracı tarafların finansal kaldıraç oranlarında değişiklikler meydana geleceği ve hem kiracı tarafın hem de kiraya veren tarafın kira konusu varlığa ilişkin amortisman gideri hesaplayacağ 1 sonuçlarına ulaşmıştır.

\section{Finansal Kiralama Kavramı}

Finansal kiralama, bir varlığın yasal mülkiyetine sahip olmaktan kaynaklanan tüm risk ve getirilerin önemli ölçüde devredildiği sözleşmedir (TFRS 16, m.62). Öte yandan finansal kiralama, bir varlığın mülkiyetinin sözleşme süresi boyunca kiralayan tarafta kalarak önceden belirlenmiş kira ödemeleri karşılığında kullanım hakkının kiracıya verilmesi ve sözleşme süresi sona erdiğinde varlığın mülkiyetinin kiracı tarafa geçmesine imkan tanıyan finansman yöntemi olarak da tanımlanabilmektedir (https://www.qnbfl.com/leasing-nedir/). Tanımlarda açıkça görüldüğü üzere, finansal kiralama işlemlerinde varlığın yasal mülkiyeti kiraya veren taraftayken, kullanım hakkı kiralayan taraftadır. Bu yönüyle finansal kiralama, faaliyet kiralamasıyla benzer özellikler taşımaktadır.

Faaliyet kiralaması, varlığın mülkiyet hakkının kiraya veren tarafta kaldığı ve risk ve getirilerin kiraya veren tarafa ait olduğu kısa süreli kiralama işlemidir. Faaliyet kiralaması, varlığın faydalı ömrünün küçük bir kısmını kapsamaktadır. Böylelikle varlık, sözleşme süresi sonunda başka bir kişi ya da kuruma kiralanabilmekte ve varlığın değeri hala iyi bir seviyede olmaktadır (Şentürk, 2016: 623). Faaliyet kiralaması, genellikle finansal kiralamanın bir türü olarak görülse de finansal kiralamadan ayrılan yönleri oldukça fazladır.

Bir kiralama işleminin finansal kiralama işlemi olarak nitelendirilebilmesi için bazı şartlar bulunmaktadır. Söz konusu şartlar standart setleri arasında ufak farklılıklar göstermiştir. TFRS 16'ya göre bir kiralama işleminin finansal kiralama olarak nitelendirilebilmesi için;

Kiralanan varlığın yasal mülkiyetinin kiralama süresi sonuna kadar kiracıya geçeceğinin düşünülmesi,

Varlığın satın alma seçeneğinin kullanılabilir hale geldiği tarihteki gerçeğe uygun değerinden oldukça düşük olması beklenen bedelle satın alma seçeneğine sahip olan kiracının, kiralama sözleşmesinin başlangıcı itibariyle kiracı tarafından bu seçeneğin kullanılmasının beklenmesi, 
- Varlığın yasal mülkiyetinin kiracıya geçmeyecek dahi olsa kira süresinin kiralanan varlı̆̆ının faydalı ömrünün büyük bir kısmını kapsaması,

· Kiralama sözleşmesinin başlangıç tarihinde kira ödemelerinin bugünkü değerinin varlığın gerçeğe uygun değerinin tamamına yakınını oluşturması,

- Varlı̆̆ın üzerinde esaslı değişiklikler yapılmadığı sürece yalnızca kiracı tarafından kullanılabilecek yapıda olması, (TFRS 16 m.63).

- Kiracının finansal kiralama işlemini feshetmesi durumunda kiraya veren tarafın fesihten kaynaklanan zararlarını karşılaması,

- Kalıntı değer ile gerçeğe uygun değerde meydana gelen değişikliklerden kaynaklanan kazanç ya da kayıpların kiraciya ait olmas1,

- Finansal kiralama sözleşmesi süresi sona erdiğinde kiracı taraf, piyasa fiyatının önemli ölçüde altında bir kira bedeli karşıllığında ikinci bir dönem için kiralamayı sürdürme hakkına sahip olması gerekmektedir (TFRS 16 Md.64).

Finansal kiralama işlemlerine konu olan varlıklar; tüketim malzemesi niteliğinde olmalı, üzerinden amortisman ayrılabilmeli, kiralama süresi sonunda temel özellikleri bozulmamalı, bir yıldan uzun süre kullanılabilmeli ve herhangi bir varlığın tamamlayıcısı olmamalıdır (https://www.resmigazete.gov.tr/eskiler/2012/12/20121213-1.htm).

\section{Türkiye Finansal Raporlama Standartları 16: Kiralamalar}

İşletmeler; 31 Aralık 2018 tarihinden önce kiralama işlemlerinin muhasebeleştirilmesi ve raporlanmasında, 24 Şubat 2004 tarihinde yürürlüğe konan ve 31.12.2005 tarihinden itibaren başlayan hesap dönemlerinde uygulanan TMS 17 standardını baz almaktaydılar. Söz konusu standardın pek çok ülkenin literatüründe eleştirilmesiyle birlikte Uluslararası Muhasebe Standartları Kurulu, UFRS 16 standardını hazırlamış ve söz konusu standart, KGK tarafından çevrilerek TFRS 16 ismiyle yayımlanmıştır. TFRS 16, ülkemizde 31 Aralık 2018 tarihinden itibaren başlayan hesap dönemlerinde uygulanmak üzere 16 Nisan 2018 tarihinde yürürlüğe girmiştir. (Uygun, 2019: 16)

\subsection{Standardın Kapsamı}

TFRS 16, alt kiralama ile kullanım hakkı elde edilen varlıkların kiralanması dahil olmak üzere tüm kiralama işlemlerini bünyesine almakla birlikte bazı istisnalar, bu standardın kapsamı dışında bırakılmıştır. Söz konusu istisnalar (TFRS 16, m.3);

· Doğalgaz, maden, petrol vb. yenilenemeyen türden doğal kaynakların araştırılması ve kullanımına ilişkin kiralamalar,

Kiracı tarafından elde tutulan canlı varlıklara (TMS 41 Tarımsal Faaliyetler standardı kapsamındaki canlı varlıklar) ilişkin kiralamalar,

· TFRS Yorum 12 kapsamına giren imtiyazlı hizmet anlaşmaları,

- TFRS 15 Müşteri Sözleşmelerinden Hasılat standardı kapsamında kiralayan tarafından verilen fikri mülkiyet lisanslar1,

TMS 38 Maddi Olmayan Duran Varlıklar standardı kapsamındaki lisans anlaşmaları çerçevesinde kiracı tarafından elde tutulan sinema filmleri, videokasetler, oyunlar, el yazmaları, patentler ve telif hakları gibi unsurlara ilişkin haklar olarak belirtilmiştir. Kiracı taraf, söz konusu istisnaların dışında kalan maddi olmayan duran varlıklarına ilişkin kiralama sözleşmelerine isterse bu standardın hükümlerini uygulayabilmektedir (TFRS 16, m.4).

Bu bağlamda, TFRS 16 standardının kapsamı içerisindeki tüm kiralama işlemleri, kiracı taraf açısından bir finansal kiralama işlemi olarak belirlenmiştir. Bununla birlikte, kısa vadeli kiralamalar ve finansal kiralama işlemine konu olan 
varlığın düşük değerli olduğu kiralamalar, kiracı tarafın tercihine bağlı olarak finansal kiralama dışında bırakılabilir (TFRS 16, m.5).

\subsection{Kiralama İșlemlerinin Sınıflandırılması}

Eski kiralama standardı TMS 17'de yer alan kiracı taraf açısından faaliyet kiralaması ve finansal kiralama ayrımı TFRS 16 standardıyla birlikte sona ermiştir (Öztürk, 2016: 13). Kiracı taraf, tüm kiralama işlemleri için aynı şekilde muhasebeleştirme yapmaktadir.

Kiraya veren taraf açısından ise finansal kiralama - faaliyet kiralaması ayrımı sürmekte, muhasebeleştirme ve raporlama işlemleri kiralama işleminin türüne göre değişiklik göstermektedir. TFRS 16, kiralama işleminin sınıflandırılmasında finansal kiralama işlemine konu olan varlığın mülkiyetinden kaynaklanan tüm risk ve getirilerin devredilmesi halinde kiralama işleminin finansal kiralama işlemi olarak nitelendirileceği, devredilmemesi halinde ise faaliyet kiralaması olarak nitelendirileceğini belirtmiştir (TFRS 16 m.62). Bu kıstasın yanı sıra bir kiralama işleminin finansal kiralama işlemi olarak nitelendirilebilmesi için (TFRS 16 m.63);

· Kiralamanın, dayanak varlı̆̆ın mülkiyetini kiralama süresinin sonuna kadar kiracıya devretmesinin öngörülmesi,

Dayanak varlığl, opsiyonun kullanılabilir hale geldiği tarihteki gerçeğe uygun değerinden yeterince düşük olması beklenen bir fiyattan satın alma opsiyonuna sahip olan kiracının, kiralama sözleşmesinin başlama tarihinde bu opsiyonu kullanacă̆ından makul ölçüde emin olması,

Dayanak varlığın mülkiyeti devredilmese dahi, kiralama süresinin dayanak varlı̆̆ın ekonomik ömrünün büyük bir kismını kapsamasi,

· Kiralama sözleşmesinin başlama tarihinde, kira ödemelerinin bugünkü dĕgerinin, dayanak varlı̆̆ın gerçeğe uygun değerinin tamamına yakınını oluşturması

· Dayanak varliğın, üzerinde büyük dĕgişiklikler yapılmadĭ̆ s sürece yalnızca kiracı tarafindan kullanılabilecek özel bir yapıda olmast.

gerekmektedir. Bu göstergelerin yanı sıra TFRS 16; tek başına veya birlikte, bir kiralama işleminin yine finansal kiralama olarak nitelendirilebilmesi için (TFRS 16 m.64);

- Kiracının kiralamayı feshedebilmesi durumunda, kiraya verenin fesihten kaynaklanan zararlarının kiracı tarafindan karşılanması,

- Kalıntı değerin gerçeğe uygun değerinde meydana gelen değişimlerden kaynaklanan kazanç veya kayıpların (örneğin kiralamanın sonundaki satıştan elde edilen bedelin büyük bir bölümüne eşit bir kira indirimi şeklinde) kiracıya ait olması

- Kiracının, piyasa fiyatının önemli ölçüde altında bir kira bedeli karşılığında ikinci bir dönem için kiralamayı sürdürme hakkının bulunması şartlarının sağlanması gerektiğini vurgulamıştır.

\subsection{Kiraya Veren Taraf İçin Finansal Kiralama İşlemleri}

Kiraya veren taraf için kiralama işlemleri, finansal kiralama ve faaliyet kiralaması olarak sınıflandırılmakta ve kiralama işleminin türüne göre muhasebeleştirme ve raporlama yapılmaktadır. Kiraya veren taraf, finansal kiralama işlemine konu olan varlığın mülkiyetinden doğan önemli risk ve getirileri kiracı tarafa devrediyorsa bu kiralama işlemi finansal kiralama olarak nitelendirilmektedir (TFRS 16, m. 61-62).

Kiraya veren taraf; kiralama sözleşmesinin başlangıç tarihinde (ilk ölçümde) finansal kiralama yoluyla elde ettiği varlıkları, finansal durum tablosuna net kiralama yatırımına eşit olacak bir tutarda ve "alacak” şeklinde muhasebeleştirmektedir. Söz 
konusu net kiralama yatırımının ölçümünde kiraya veren taraf, zımni faiz oranını kullanmaktadır (TFRS 16, m. 67-68). Sonraki ölçümlerde ise muhasebeleştirme işlemi, finansal kiralama işlemine konu olan varlıkla ilgili net yatırımdaki sabit bir dönemsel getiri oranı temel alınmak ve anapara ve kazanılmamış finansman geliri düşürülmek suretiyle gerçekleştirilmektedir (TFRS 16, m. 75-76).

Eski kiralama standardı olan TMS 17 ile güncel kiralama standardı TFRS 16 karşılaştırılmalı olarak incelendiğinde TFRS 16'da kiracı taraf için önemli değişiklikler yapılmış olmasına karşın kiraya veren taraf açısından önemli bir değişikliğin olmadığı saptanmıştır.

\subsection{Kiracı Taraf İçin Kiralama İşlemleri}

Kiracı taraf, finansal kiralamaya konu olan varlığı kiralayan kişi ve kuruluşlardır. Söz konusu taraf için belirli bir kıstas bulunmamakla birlikte hukuki işlem gerçekleştirebilen tüm gerçek ve tüzel kişiler, kiracı taraf olabilmektedir.

Kiracı taraf açısından finansal kiralama - faaliyet kiralaması ayrımı, TFRS 16'yla son bulmuştur. Kiracı taraflar, söz konusu standartla birlikte tüm kiralama işlemleri için aynı şekilde muhasebeleştirme ve raporlama işlemlerini gerçekleştirmektedir.

Kiracı taraf, kiralamaya konu varlığı finansal durum tablosuna yansıtırken TMS 17'deki gibi varlığın gerçeğe uygun değeri ile kira ödemelerini kıyaslamamakta (TMS 17, m.20), direkt olarak kira ödemelerinin bugünkü değeri üzerinden raporlama yapmaktadır (TFRS 16, m.26). Kiracı taraf, söz konusu ödemelerin bugünkü değerini saptarken zımni faiz oranını kullanmaktadır. Zımni faiz oranı, kolaylıkla belirlenemiyorsa bu durumda kiracının alternatif borçlanma faiz oranı kullanılmaktadır (TFRS 16 m. 26). Aynı zamanda TFRS 16'da varlığa ilişkin ilk muhasebeleştirme işleminin varlığın maliyeti üzerinden yapılacağı açıkça belirtilmiş, TMS 17'deki gibi yoruma açık bir şekilde bırakılmamıştır (Öztürk, 2016: 16).

Finansal kiralamaya konu olan varlığın sonraki dönemlerde ölçülmesinde ise TFRS 16, kiracı tarafa TMS 17'de yer alan maliyet yönteminin yanı sıra gerçeğe uygun değer yöntemini seçenek olarak sunmaktadır.

Kiracı taraf, finansal kiralamaya konu olan varlığın değerlemesinde gerçeğe uygun değer yöntemini kullanabilmesi için; yatırım amaçlı gayrimenkullerine TMS 40 Yatırım Amaçı Gayrimenkuller'de yer alan gerçeğe uygun değer yöntemini uygulaması gerekmektedir (TFRS 16 m. 34)

Finansal kiralamaya konu olan varlı̆̆a ilişkin kira ödemelerinin sonraki dönemlerde ölçümü şu şekilde gerçekleştirilmektedir (TFRS 16 m.36);

Kira yükümlülüğünde yer alan faiz tutarı, varlığın defter değerine eklenir.

Ödemesi gerçekleştirilen kira bedeli, varlığın defter değerinden düşürülür.

Finansal kiralama işlemine ilişkin yapılan değişiklikler ve tekrarlanan değerlendirmeler gözden geçirilmek suretiyle sabit kira ödemeleri yansitılacak şekilde defter değeri yeniden ölçülür.

Aynı zamanda kiracı taraf, kiralamanın başladığı tarihten sonra kira yükümlülüğüne ilişkin faizi ve o dönemde gerçekleşen, kira yükümlülüğü ölçümü kapsamına girmeyen değiş̧en kira ödemelerini kâr veya zarara yansıtmak durumundadır (TFRS m. 38). Kira süresinin değiştirilmesi veya varlığa ilişkin satın alma opsiyonunun kullanılması durumunda ise kiracı taraf, yeni kira süresini, düzeltilmiş kira ödemelerini ve düzeltilmiş iskonto oranını dikkate alarak kira yükümlülüğünü yeniden değerlemektedir (Marşap ve Yanık, 2018: 34).

\subsection{Yeni Kiralama Standardı TFRS 16 ile Eski Kiralama Standardı TMS 17 Standartlarının Karşılaştırılması}

Yeni kiralama standardının yayınlanmasıyla birlikte kiralama işlemlerinin sınıflandırılması, muhasebeleştirilmesi, raporlanması gibi hususlarda önemli değişiklikler meydana gelmiştir. Çalışmanın bu bölümünde standartlar, bahsedilen hususlar açısından karşılaştırılarak maddeler halinde sunulacaktır. 
TMS 17 standardında faaliyet kiralaması "finansal kiralama kapsamına girmeyen kiralamalar" olarak tanımlanmaktayken (TMS 17, p. 4,s.2) TFRS 16 standardında "kiralama konusu varlığın mülkiyetinden doğan tüm risk ve getirilerin önemli ölçüde devredilmediği kiralamalar” olarak tanımlanmaktadır (TFRS 16, Ek A, s.16).

Eski kiralama standardında kiralama işlemleri, kiracı ve kiraya veren taraflar açısından faaliyet kiralaması ve finansal kiralama olmak üzere ikiye ayrılırken TFRS 16 standardında kiracı taraf açısından finansal kiralama faaliyet kiralaması ayrımına son verilmiştir.

Dayanak varlığın finansal tablolara alınması bakımından söz konusu iki standart karşılaştırıldığında standartlar arasında önemli farklılıklar göze çarpmaktadır. TMS 17 standardında faaliyet kiralamalarından doğan varlık ve yükümlülükler, finansal durum tablosunda sunulmamaktaydı. Dolayısıyla dayanak varlığın ilk ölçümü, bir anlam ifade etmemekteydi. TFRS 16 standardında ise kiracı taraf, kiralamanın fiili olarak başladığı tarihte kira türü fark etmeksizin zımni faiz oranı/alternatif borçlanma faiz oranını kullanarak dayanak varlığa ilişkin varlık ve yükümlülük kalemlerini, varlığın bugünkü değeriyle finansal durum tablosuna yansıtmaktadır (TFRS 16, p.22, s.4).

Eski kiralama standardında dayanak varlığın sonraki dönemlerde ölçümü işlemi, kiralamanın fiili olarak başladığı tarihte finansal durum tablosuna varlık ve yükümlülük yansıtılmadığı için söz konusu değildi. Kiralama işlemine ilişkin yapılan ödemeler, ödemenin yapıldığı dönemde gider olarak muhasebeleştirilmekteydi (TMS 17, p.33, s.8). TFRS 16 standardı, bahsedilen duruma da bir yenilik getirerek kiralama konusu varlığa ilişkin varlık ve yükümlülük kalemlerinin sonraki dönemlerde ölçümünün yapılması gerektiğini belirtmiştir. Kiracı taraf, varlığın sonraki dönemlerdeki ölçümünde amortisman ayırırken varlığın mülkiyetinin kira süresi sonunda kendisine geçip geçmeyeceği durumunu ele alır. Kira süresi sonunda varlığın mülkiyetinin kiracı tarafa geçecek olması durumunda kiracı taraf, varlığın faydalı ömrünü, diğer durumlarda ise varlığın faydalı ömrüyle kira süresini kıyaslayarak daha az süreye sahip olanı dikkate alarak amortisman ayırır (TFRS 16, p.32, s.5).

Kiracı taraf, kira yükümlülüğünü sonraki dönemlerde ölçerken; faizi, ödemesi yapılan kira taksitlerini ve yeniden değerlemeleri, varsa yapılan değişiklikleri ya da revize edilmiş özü itibariyle sabit kira ödemelerini yansıtacak şekilde ölçmelidir (TFRS 16, p.36, s.6). Kiracı, kira yükümlülüğünden doğan faiz giderini hesaplarken zımni faiz oranı veya alternatif borçlanma faiz oranını veya revize edilmiş iskonto oranını kullanmalıdır (TFRS 16, p.37, s.6).

4. Maddede belirtildiği gibi eski kiralama standardının kullanıldığı dönemlerde kiracı taraf, kira ödemelerini, ödemenin yapıldığı dönemde gider olarak muhasebeleştirmekteydi. Varlığa ilişkin bir varlık ve yükümlülük raporlaması söz konusu değildi. Ancak TFRS 16 standardında kiracı tarafın, kira konusu varlığa ilişkin finansal durum tablosunda varlık ve yükümlülük raporlaması sebebiyle dönem sonunda varlıktan doğan amortisman giderini, yükümlülükten doğan faiz giderini gelir tablosunda birbirinden ayrı olarak sunmalıdır (TFRS 16, p.49,s.7).

\section{Türkiye Finansal Raporlama Standartları 16: Kiralamalar Standardının Borsa İstanbul Şirketlerinin Finansal Tablolarına Etkisi Üzerine Bir Araştırma}

\subsection{Araștırmanın Amacı ve Önemi}

BİST 100 endeksi; Borsa İstanbul'da işlem gören, piyasa ve işlem hacmi yönüyle en yüksek 100 hisse senedinin performansının ölçülmesinde kullanılan temel gösterge olarak tanımlanmaktadır. Söz konusu endeks, yatırımcılar açısından oldukça önem arz etmektedir. BİST 100 endeksinin borsanın genel durumunu yansıtması, yatırımcıların söz konusu endekse verdiği önemin en önemli sebebi olarak belirtilebilmektedir (https://www.ekonomist.com.tr/encyclopedia/bist-100-endeksi).

Yatırımcıların BİST 100 endeksinde yer alan hisselere yatırım yapma kararı alırken göz önüne aldığı en önemli göstergelerden bazıları; şirketlerin finansal oranları ve finansal tablolarıdır. Bilindiği üzere finansal oranlar ve finansal tablolar, finansal tablo kalemlerinden oluşmakta olup, söz konusu kalemlerde yapılacak değişiklikler finansal oranları ve finansal tabloları doğrudan etkilemektedir. 1 Ocak 2019 tarihinden itibaren eski kiralama standardı TMS 17'nin uygulamadan kaldırılması ve TFRS 16 standardının uygulanmaya başlanması, BİST 100 şirketlerinin varlık, yükümlülük ve kâr kalemleri gibi önemli 
finansal tablo kalemlerinin etkilenmesine sebep olmuştur. Bu durumun bir sonucu olarak söz konusu şirketlerin finansal tablo ve finansal oranları da değişim göstermiştir. Bu bağlamda araştırmanın amacı; yeni kiralama standardı TFRS 16'nın BİST 100 endeksinde faaliyet gösteren işletmelerin ve sektörlerin finansal tabloları ve oranlarına etkisinin tespit edilmesi ve söz konusu standardın kullanıldığ nicel ve nitel farkların analiz edilmesidir.

\subsection{Araştırmanın Kapsamı}

Araştırma kapsamında, BİST 100 endeksinde yer alan işletmelerin finansal verileri kullanılmıştır. BİST 100 endeksinde yer alan işletmelerden mali kuruluşlar ve holdingler, araştırmanın kapsamına dahil edilmemiştir. TFRS 16'nın etkisinin ölçülmesi amacıyla geriye kalan 65 şirketin; yeni kiralama standardına geçişten önceki ve sonraki 2 yıla ait finansal tabloları ve dipnotları incelenmiştir. Bu bağlamda 2017, 2018, 2019 ve 2020 yıllarına ait finansal tablolar ve dipnotlar kıyaslanmış ve analiz edilmiştir. Öte yandan Fenerbahçe Futbol A.Ş de araştırma kapsamına dahil edilmemiştir. Söz konusu şirketin bir futbol kulübü olmasından dolayı finansal tablo döneminin bir önceki yılın Mayıs ayında başlayıp, bu yılın Mayıs ayında bitecek olması ve genellikle finansal tablolarını Ağustos ayında yayınlaması, araştırma kapsamına dahil edilememesine sebep olmuştur.

\subsection{TFRS 16'nın BİST 100 Endeksinde Faaliyet Gösteren Şirketlerin Finansal Tabloları Üzerinde Etkisinin Ölçülmesi}

Araştırmanın bu bölümünde TMS 17'den TFRS 16'ya geçişin BİST 100 endeksinde faaliyet gösteren şirketlerin finansal tablo kalemleri ve finansal oranları üzerindeki etkileri incelenecektir. Araştırma çerçevesinde öncelikle TFRS 16 standardının BİST 100 şirketlerinin finansal durum tablosu ve gelir tablosunda yer alan ve kiralama işlemlerinin etkilediği finansal tablo kalemlerindeki değişimler incelenecek devamında ise söz konusu standardın örneklemde yer alan şirketlerin finansal oranlarına etkisi değerlendirilecektir. Araştırmanın devamında ise yeni kiralama standardının finansal tablo kalemlerine ve finansal oranlarına etkisi, sektörel bazda analiz edilecektir. Finansal tablo kalemleri ve finansal oranlar, hem örneklemin bütünü hem de sektörel bazda analiz edilirken şirketlerin başlica finansal tablo kalemleri toplanacak ve elde edilen toplam tutarlarla birlikte bu tutarlar üzerinden ortaya çıkan finansal oranlar, tablolar halinde raporlanacaktır. Son olarak örneklemde yer alan şirketlerin bağımsız denetçi raporlarında bulunan kilit denetim konuları incelenecektir. İnceleme sonucunda hangi sektörde kaç işletmenin kilit denetim konularında TFRS 16'nın yer aldığı sunulacaktır.

Başlangıçta örneklemde yer alan işletmeler, tek bir işletme gibi kabul edilecek ve söz konusu şirketlerin finansal durum tablosu ve gelir tablolarında yer alan, kiralama işlemlerinin etkilediği finansal tablo kalemlerinin TMS 17 ve TFRS 16 uygulandığı dönemlerde tutarları ve değişimleri tablo halinde belirtilecektir.

Tablo 1: Örneklemde Yer Alan Şirketlerin TMS 17 ve TFRS 16 Uyguladığı Dönemlerde Finansal Durum Tablosu ve Gelir Tablolarında Yer Alan Başlıca Finansal Tablo Kalemlerinin Tutarları ve Değişimleri

\begin{tabular}{|c|c|c|c|c|}
\hline & \multicolumn{2}{|c|}{ TMS 17} & \multicolumn{2}{|c|}{ TFRS 16} \\
\hline & 2017 & 2018 & 2019 & 2020 \\
\hline Dönem Kârı & 24.328 .317 .193 & 28.602 .540 .446 & 35.124 .960 .599 & 31.776 .497 .813 \\
\hline $\begin{array}{l}\text { Dönem Kârında Bir Önceki Yıla } \\
\text { Göre Değişim (\%) }\end{array}$ & - & 17,56 & 22,8 & $-9,53$ \\
\hline $\begin{array}{l}\text { Finansman Gideri Öncesi Faaliyet } \\
\text { Kâr1 }\end{array}$ & 46.949.028.545 & 66.127 .666 .128 & 69.856 .827 .649 & 77.011 .600 .027 \\
\hline $\begin{array}{l}\text { Finansman Gideri Öncesi Faaliyet } \\
\text { Kârında Bir Önceki Yıla Göre } \\
\text { Değişim (\%) }\end{array}$ & - & 40,85 & 5,63 & 10,24 \\
\hline Esas Faaliyet Kârı & 41.801 .446 .926 & 61.006 .776 .879 & 63.932 .080 .860 & 70.270 .296 .966 \\
\hline $\begin{array}{l}\text { Esas Faaliyet Kârında Bir Önceki } \\
\text { Yıla Göre Değişim (\%) }\end{array}$ & - & 45,94 & 4,79 & 9,91 \\
\hline Faiz Gideri & 9.004 .287 .984 & 15.100 .494 .482 & 23.221 .490 .350 & 21.972 .843 .711 \\
\hline $\begin{array}{l}\text { Faiz Giderinde Bir Önceki Yıla } \\
\text { Göre Değişim (\%) }\end{array}$ & 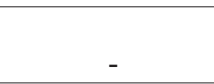 & 67,7 & 53,77 & $-5,38$ \\
\hline
\end{tabular}




\begin{tabular}{|l|c|c|c|c|}
\hline Kiralama İşlemlerinden Doğan & & & & \\
Faiz Gideri & - & - & 4.484 .838 .584 & 4.850 .718 .609 \\
\hline $\begin{array}{l}\text { Kiralama İşlemlerinden Doğan } \\
\text { Faiz Giderinde Bir Önceki Yıla } \\
\text { Göre Değişim (\%) }\end{array}$ & - & - & & \\
\hline Toplam Varlıklar & 461.233 .163 .288 & 607.540 .023 .254 & 748.931 .855 .523 & 930.400 .681 .273 \\
\hline $\begin{array}{l}\text { Toplam Varlıklarda Bir Önceki } \\
\text { Y1la Göre Değişim (\%) }\end{array}$ & - & 31,72 & 23,27 & 24,23 \\
\hline Toplam Yükümlülükler & 298.971 .575 .861 & 389.127 .240 .032 & 484.463 .591 .262 & 614.047 .109 .850 \\
\hline $\begin{array}{l}\text { Toplam Yükümlülüklerde Bir } \\
\text { Önceki Ylla Göre Değişim (\%) }\end{array}$ & - & 30,15 & 24,5 & 26,74 \\
\hline
\end{tabular}

Örneklemde yer alan şirketlerin finansal tablo kalemleri incelendiğinde finansman gideri öncesi faaliyet kârı, esas faaliyet kârı, toplam varlıklar ve toplam yükümlülükler kalemlerinde sürekli olarak artış görülmektedir. TFRS 16'nın kullanılmaya başlanmasından sonra toplam varlıklarda ve toplam yükümlülüklerde görülen artışın sebeplerinden biri olarak şirketlerin söz konusu standartla birlikte kiralanan varlıklara ilişkin varlık ve yükümlülük raporlaması belirtilebilir. Öte yandan finansman gideri öncesi faaliyet karının ve esas faaliyet karının artış göstermesinin sebeplerinden biri olarak TMS 17'ye göre faaliyet kiralamalarından doğan kira giderlerinin TFRS 16 standardına göre işletmelerin gelir tablolarında yer almaması söylenebilir.

Gözden geçirilen bir diğer husus, söz konusu işletmelerin TMS 17 ve TFRS 16 uyguladığı dönemlerdeki finansal oranları ve finansal oranlardaki değişimlerdir. Örneklemde yer alan şirketlerin 2017, 2018, 2019 ve 2020 yıllarındaki finansal oranları ve bu oranlardaki değişimler Tablo 4'de belirtilmiştir.

Tablo 2: Örneklemde Yer Alan Şirketlerin TMS 17 ve TFRS 16 Uyguladığı Dönemlerdeki Finansal Oranları ve Değişimleri

\begin{tabular}{|l|c|c|c|c|}
\hline & \multicolumn{2}{|c|}{ TMS 17 } & \multicolumn{2}{c|}{ TFRS 16 } \\
\hline & $\mathbf{2 0 1 7}$ & $\mathbf{2 0 1 8}$ & $\mathbf{2 0 1 9}$ & $\mathbf{2 0 2 0}$ \\
\hline Aktif Kârlılık & 5,27 & 4,7 & 4,69 & $-1,28$ \\
\hline $\begin{array}{l}\text { Aktif Kârlılıkta Bir Önceki Yıla Göre } \\
\text { Değişim }\end{array}$ & - & $-0,57$ & $-0,01$ & 65,99 \\
\hline Toplam Borç / Toplam Varlıklar & 64,82 & 64,05 & 64,68 & 1,31 \\
\hline $\begin{array}{l}\text { Toplam Borç / Toplam Varlıklar } \\
\text { Oranında Bir Önceki Yıla Göre Değişim }\end{array}$ & - & $-0,77$ & 0,63 & 22,81 \\
\hline Net Kâr Marji & 28,22 & 23,68 & 27,2 & $-4,39$ \\
\hline $\begin{array}{l}\text { Net Kâr Marjında Bir Önceki Yıla Göre } \\
\text { Değişim }\end{array}$ & - & $-4,54$ & 3,52 & 50,44 \\
\hline Faaliyet Kâr Marji & 48,49 & 50,52 & 49,52 & \\
\hline $\begin{array}{l}\text { Faaliyet Kâr Marjinda Bir Önceki Yıla } \\
\text { Göre Değişim }\end{array}$ & - & 2,03 & $-1,03$ & 0,92 \\
\hline
\end{tabular}

Tablo 2'de görüldüğü üzere; şirketlerin aktif kârlılık oranı, sürekli bir düşüş göstermiştir. Aktif kârlılık oranı, dönem net kârının toplam varlıklara bölünmesiyle elde edilmektedir. Dolayısıyla toplam varlıklarda gerçekleşen yüzdesel değişimin, dönem net kârında gerçekleşen yüzdesel değişimden fazla olması, aktif kârlılığı azaltmaktadır. Yeni kiralama standardının uygulanması, şirketlerin toplam varlıklarında artış, dönem kârında ise azalışa sebep olmaktadır. Dolayısıyla aktif karlılıkta meydana gelen azalışta TFRS 16'nın da etkisi olduğu söylenebilir. Ayrıca Tablo 6'da da görüleceği üzere; şirketlerin toplam varlıklarındaki yüzdesel değişim, sürekli olarak dönem kârındaki yüzdesel değişimden yüksektir. Bu durum, aktif kârlılık oranındaki sürekli düşüşü açıklar niteliktedir. Öte yandan net kâr marjı ve faaliyet kâr marjı oranlarında sürekli bir şekilde artış ya da düşüş görülmemektedir. Bu durumun sebebi şirketlerin net satışlarındaki yüzdesel değişimlerdir. Şirketlerin net satışlarının yüzdesel değişimlerinin, esas faaliyet kârındaki ve finansman gideri öncesi faaliyet kârındaki yüzdesel değişimlerden fazla olması, söz konusu oranları düşürmüş; az olması ise söz konusu oranları artırmıştır.

Çalışmanın devamında yeni kiralama standardının finansal tablo kalemleri ve finansal oranlara etkisi sektörel bazda değerlendirilecektir. İşletme sayısı 3'ten az olan sektörler, değerlendirme kapsamına alınmamıştır. Mali kuruluşlar ve holdingler hariç olmak üzere BİST 100 şirketleri ve dahil olduğu sektörler Tablo 5'te sunulmuştur. 


\begin{tabular}{|l|c|}
\hline Tablo 3: Sektörlere Göre Şirket Sayısı & Şirket Sayısı \\
\hline Sektör & 41 \\
\hline İmalat & 7 \\
\hline Toptan ve Perakende Ticaret, Otel ve Lokantalar & 5 \\
\hline Elektrik, Gaz ve Su & 4 \\
\hline Ulaştırma, Haberleşme ve Depolama & 3 \\
\hline Teknoloji & 3 \\
\hline Madencilik ve Taş Ocakçıllı̆̆1 & 1 \\
\hline Eğitim, Sağlık, Spor ve Diğer Hizmetler & 1 \\
\hline Gayrimenkul Faaliyetleri & $\mathbf{6 5}$ \\
\hline TOPLAM & \\
\hline
\end{tabular}

Çalışmanın başlangıcında örneklemin tamamı için yapılan analizler, çalışmanın bu bölümünde imalat sektöründe faaliyet gösteren işletmeler için yapılacaktır. Tablo 4 ve Tablo 5'de imalat sektöründe faaliyet gösteren şirketlerin finansal durum tablosu ve gelir tablolarında yer alan, kiralama işlemlerinin etkilediği finansal tablo kalemlerinin tutarları, değişimleri ve finansal oranları gösterilecektir.

Tablo 4: İmalat Sektöründe Faaliyet Gösteren Şirketlerin TMS 17 ve TFRS 16 Uyguladığı Dönemlerde Finansal Durum Tablosu ve Gelir Tablolarında Yer Alan Başlıca Finansal Tablo Kalemlerinin Tutarları ve Değişimleri

\begin{tabular}{|c|c|c|c|c|}
\hline & \multicolumn{2}{|c|}{ TMS 17} & \multicolumn{2}{|c|}{ TFRS 16} \\
\hline & 2017 & 2018 & 2019 & 2020 \\
\hline Dönem Kârı & 14.763 .727 .817 & 17.674 .137 .715 & 14.964 .975 .225 & 18.795 .644 .587 \\
\hline $\begin{array}{l}\text { Dönem Kârında Bir Önceki Yıla Göre Değişim } \\
(\%)\end{array}$ & - & 19,72 & $-15,33$ & 25,59 \\
\hline Finansman Gideri Öncesi Faaliyet Kârı & 23.695 .736 .439 & 32.683 .484 .975 & 27.346 .567 .702 & 35.658 .225 .578 \\
\hline $\begin{array}{l}\text { Finansman Gideri Öncesi Faaliyet Kârında Bir } \\
\text { Önceki Yıla Göre Değişim (\%) }\end{array}$ & - & 37,93 & $-16,33$ & 30,39 \\
\hline Esas Faaliyet Kârı & 21.911 .601 .165 & 30.360 .580 .534 & 24.770 .337 .293 & 32.202 .283 .855 \\
\hline $\begin{array}{l}\text { Esas Faaliyet Kârında Bir Önceki Yıla Göre } \\
\text { Değişim (\%) }\end{array}$ & - & 38,56 & $-18,41$ & 30 \\
\hline Faiz Gideri & 3.703 .097 .907 & 6.473 .672 .781 & 9.780 .602 .386 & 8.659 .555 .619 \\
\hline Faiz Giderinde Bir Önceki Yıla Göre Değişim (\%) & - & 74,82 & 51,08 & $-11,46$ \\
\hline Kiralama İşlemlerinden Doğan Faiz Gideri & - & - & 353.397 .841 & 420.030 .354 \\
\hline $\begin{array}{l}\text { Kiralama İşlemlerinden Doğan Faiz Giderinde Bir } \\
\text { Önceki Yıla Göre Değişim (\%) }\end{array}$ & - & - & - & 18,85 \\
\hline Toplam Varlıklar & 223.520 .298 .103 & 279.718.963.062 & 334.935 .495 .382 & 416.584 .823 .590 \\
\hline $\begin{array}{l}\text { Toplam Varlıklarda Bir Önceki Yıla Göre Değişim } \\
(\%)\end{array}$ & - & 25,14 & 19,74 & 24,37 \\
\hline Toplam Yükümlülükler & 133.458 .823 .218 & 164.178.530.595 & 199.858.719.591 & 250.739 .768 .514 \\
\hline $\begin{array}{l}\text { Toplam Yükümlülüklerde Bir Önceki Yıla Göre } \\
\text { Değişim (\%) }\end{array}$ & - & 23,02 & 21,73 & 25,45 \\
\hline
\end{tabular}

İmalat sektöründe faaliyet gösteren işletmelerin, başlıca finansal tablo kalemleri analiz edildiğinde, örneklemin bütününe zıt olarak; dönem kârının 2019 yılında azalış, 2020 yılında artış gösterdiği, finansman gideri öncesi faaliyet kârının ve esas faaliyet kârının 2019 yılında azalış gösterdiği görülmektedir. Öte yandan faiz gideri, toplam varlıklar ve toplam yükümlülükler kalemleri; örneklemin bütünüyle aynı şekilde artış ya da azalış göstermiştir. 
Tablo 5: İmalat Sektöründe Faaliyet Gösteren Şirketlerin TMS 17 ve TFRS 16 Uyguladığ Dönemlerdeki Finansal Oranlar1 ve Değişimleri

\begin{tabular}{|c|c|c|c|c|}
\hline & \multicolumn{2}{|c|}{ TMS 17} & \multicolumn{2}{|c|}{ TFRS 16} \\
\hline & 2017 & 2018 & 2019 & 2020 \\
\hline Aktif Kârlılık & 6,6 & 6,31 & 4,47 & 4,51 \\
\hline $\begin{array}{l}\text { Aktif Kârlılıkta Bir Önceki Yıla Göre } \\
\text { Değișim }\end{array}$ & - & $-0,29$ & $-1,84$ & 0,04 \\
\hline Toplam Borç / Toplam Varlıklar & 59,71 & 58,69 & 59,67 & 60,19 \\
\hline $\begin{array}{l}\text { Toplam Borç / Toplam Varlıklar } \\
\text { Oranında Bir Önceki Y1la Göre Değişim }\end{array}$ & - & 0,98 & 0,98 & 0,52 \\
\hline Net Kâr Marj1 & 36,21 & 30,36 & 27,32 & 28,09 \\
\hline $\begin{array}{l}\text { Net Kâr Marjında Bir Önceki Yıla Göre } \\
\text { Değişim }\end{array}$ & - & $-5,85$ & $-3,04$ & 0,77 \\
\hline Faaliyet Kâr Marj1 & 53,75 & 52,16 & 45,23 & 48,13 \\
\hline $\begin{array}{l}\text { Faaliyet Kâr Marjında Bir Önceki Yıla } \\
\text { Göre Değișim }\end{array}$ & - & $-1,59$ & $-6,93$ & 2,9 \\
\hline
\end{tabular}

İmalat sektöründe faaliyet gösteren işletmelerin finansal oranları incelendiğinde, söz konusu oranların örneklemin bütününe zıt hareket ettiği görülmüştür. Bu zıtlıklardan ilki, 2020 yılında aktif kârlılık oranında görülen artıştır. 2020 yılında, şirketlerin dönem kârının bir önceki yıla göre \%25,59 artmasına karşın toplam varlıklarının \%24,37 artması, aktif kârlılık oranında olumlu bir artışa sebep olmuştur. Öte yandan şirketlerin net kâr marjında 2018 ve 2019 yıllarında azalış, 2020 yılında ise artış görülmektedir. 2018 yılında dönem kârının \%19,72 artmasına karşın net satışların \%42,77 artması, 2019 yılında dönem kârının \%15,33 azalmasına karşın net satışların \%5,92 azalması, net kâr marjındaki azalışları açıklamaktadır. 2020 yılında ise dönem kârının \%25,59 artmasına karşın net satışların \%22,18 artması, net kâr marjının artmasına sebep olmuştur. Faaliyet kâr marjı incelendiğinde de 2018 ve 2019 yıllarında azalış, 2020 yılında artış görülmektedir. Bu durumun sebebi net kâr marjındaki sebeple aynıdır. 2018 ve 2019 yıllarında esas faaliyet kârındaki yüzdesel değişimin net satışlardaki yüzdesel değişimlerden düşük olması, azalışları; 2020 yılında esas faaliyet kârındaki yüzdesel değişimin (\%30), net satışlardaki yüzdesel değişimden $(\% 22,18)$ fazla olması faaliyet kâr marjındaki artışı açıklamaktadır.

Tablo 6 ve Tablo 7'de TFRS 16'nın Toptan ve Perakende Ticaret, Otel ve Lokantalar sektöründe faaliyet gösteren işletmelerin finansal durum tablosu ve gelir tablolarında yer alan, kiralama işlemlerinin etkilediği finansal tablo kalemlerinin tutarları, değişimleri ve finansal oranları sunulmuştur.

Tablo 6: Toptan ve Perakende Ticaret, Otel ve Lokantalar Sektöründe Faaliyet Gösteren Sirketlerin TMS 17 ve TFRS 16 Uyguladığ 1 Dönemlerde Finansal Durum Tablosu ve Gelir Tablolarında Yer Alan Başlıca Finansal Tablo Kalemlerinin Tutarları ve Değişimleri

\begin{tabular}{|c|c|c|c|c|}
\hline & \multicolumn{2}{|c|}{ TMS 17} & \multicolumn{2}{|c|}{ TFRS 16} \\
\hline & 2017 & 2018 & 2019 & 2020 \\
\hline Dönem Kâr1 & 1.539 .478 .781 & 1.027 .191 .656 & 1.182 .309 .864 & 4.190 .452 .316 \\
\hline Dönem Kârında Bir Önceki Yıla Göre Değişim (\%) & - & $-33,28$ & 15,1 & 254,42 \\
\hline Finansman Gideri Öncesi Faaliyet Kârı & 3.575 .422 .666 & 3.390 .858 .939 & 5.343 .303 .259 & 8.793 .913 .053 \\
\hline $\begin{array}{l}\text { Finansman Gideri Öncesi Faaliyet Kârında Bir Önceki Yıla } \\
\text { Göre Değişim (\%) }\end{array}$ & - & $-5,16$ & 57,58 & 64,58 \\
\hline Esas Faaliyet Kârı & 2.385.379.936 & 3.306 .470 .276 & 4.979.171.612 & 8.165 .114 .457 \\
\hline Esas Faaliyet Kârında Bir Önceki Yıla Göre Değişim (\%) & - & 38,61 & 50,59 & 63,99 \\
\hline Faiz Gideri & 1.021 .732 .857 & 1.172 .359 .796 & 2.852 .411 .895 & 2.871 .346 .625 \\
\hline Faiz Giderinde Bir Önceki Yıla Göre Değişim (\%) & - & 14,74 & 143,3 & 0,6 \\
\hline Kiralama İşlemlerinden Doğan Faiz Gideri & - & - & 1.685 .350 .857 & 1.819 .827 .726 \\
\hline $\begin{array}{l}\text { Kiralama İşlemlerinden Doğan Faiz Giderinde Bir Önceki } \\
\text { Yıla Göre Değişim (\%) }\end{array}$ & - & - & 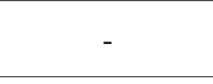 & 7,98 \\
\hline Toplam Varlıklar & 31.927 .050 .131 & 36.116 .270 .986 & 50.993 .223 .820 & 68.342 .365 .106 \\
\hline Toplam Varlıklarda Bir Önceki Yıla Göre Değişim (\%) & - & 13,12 & 41,19 & 34,02 \\
\hline Toplam Yükümlülükler & 26.052.522.044 & 27.784 .392 .585 & 41.859 .526 .992 & 54.647 .596 .345 \\
\hline Toplam Yükümlülüklerde Bir Önceki Yıla Göre Değişim (\%) & - & 6,64 & 50,65 & 30,55 \\
\hline
\end{tabular}


Toptan ve perakende ticaret, otel ve lokantalar sektöründe faaliyet gösteren işletmelerin finansal tablo kalemleri incelendiğinde, göze çarpan en büyük değişim 2020 yılında dönem kârında meydana gelen artıştır. Söz konusu artışın en temel sebebi, sektörün önde gelen şirketlerinden Şok ve Teknosa şirketlerinin 2019 yılında zarar açıklarken 2020 yılında kâr açıklamasıdır. Şok şirketi, 2020 yılında net satışlarını 2019 yılına göre \%34 artırmış ve böylece 2019 yılında 298.637 .678 TL zarar açıklarken 2020 yılında 272.612.688 TL kâr açıklamıştır. Teknosa şirketi ise 2019 yılında 148.634.000 TL zarar açıklarken 2020 yılında 85.296.000 kâr açıklamıştır. Dolayısıyla bu iki şirketin kâr açıklamasıyla birlikte 2020 yılında toptan ve perakende ticaret, otel ve lokantalar sektörünün dönem kârında 805.180.066 TL'lik bir artış meydana gelmiştir. Öte yandan BİM işletmesinin net satışlarını \%44,89 artırarak 2020 yılında 2019 yılına göre 1.381.938.000 TL daha fazla kâr açıklaması ve Doğuş işletmesinin satışlarını \%94,93 artırarak 2020 yılında 2019 yılına göre 961.557.000 TL daha fazla kâr açıklaması da artışın sebepleri arasında sayılabilir. Söz konusu şirketlerin giderlerindeki değişimin; satışlardaki değişime göre çok daha az artış göstermesi, bu artışın bir diğer sebebidir. Diğer finansal tablo kalemleri değerlendirildiğinde toplam varlıkların ve toplam yükümlülüklerin, örneklemin bütününe paralel olarak artış gösterdiği, kalan finansal tablo kalemlerinin örnekleme zıt hareket ettiği saptanmıştır.

Tablo 7: Toptan ve Perakende Ticaret, Otel ve Lokantalar Sektöründe Faaliyet Gösteren Şirketlerin TMS 17 ve TFRS 16 Uyguladığ1 Dönemlerdeki Finansal Oranları ve Değişimleri

\begin{tabular}{|l|c|c|c|c|}
\hline & \multicolumn{2}{|c|}{ TMS 17 } & \multicolumn{2}{c|}{ TFRS 16 } \\
\hline & $\mathbf{2 0 1 7}$ & $\mathbf{2 0 1 8}$ & $\mathbf{2 0 1 9}$ & 6,13 \\
\hline Aktif Kârlılık & 4,82 & 2,84 & 2,31 & 3,82 \\
\hline $\begin{array}{l}\text { Aktif Kârlııı Bir Önceki Yıla Göre } \\
\text { Değişim }\end{array}$ & - & $-1,98$ & $-0,57$ & 79,96 \\
\hline Toplam Borç/ Toplam Varlıklar & 81,6 & 76,93 & 82,08 & $-2,12$ \\
\hline $\begin{array}{l}\text { Toplam Borç / Toplam Varlıklar } \\
\text { Oranında Bir Önceki Yıla Göre Değişim }\end{array}$ & - & $-4,67$ & 5,15 & 14,62 \\
\hline Net Kâr Marji & 11,19 & 5,77 & 5,45 & 9,17 \\
\hline $\begin{array}{l}\text { Net Kâr Marjında Bir Önceki Yıla Göre } \\
\text { Değişim }\end{array}$ & - & $-5,42$ & $-0,22$ & 28,49 \\
\hline Faaliyet Kâr Marji & 17,33 & 18,59 & 22,93 & 5,56 \\
\hline $\begin{array}{l}\text { Faaliyet Kâr Marjinda Bir Önceki Yıla } \\
\text { Göre Değişim }\end{array}$ & - & 1,26 & 4,34 & \\
\hline
\end{tabular}

Toptan ve perakende ticaret, otel ve lokantalar sektöründe faaliyet gösteren işletmelerin finansal oranları değerlendirildiğinde; aktif kârlılık oranının örneklemin bütününe zıt, imalat sektörüne paralel olarak 2020 yılında artış gösterdiği saptanmıştır. Söz konusu sektörde 2020 yılında dönem kârının \%254,42 artmasına karşın toplam varlıkların \%34,02 artması, aktif kârlılık oranının artmasına sebep olmuştur. Öte yandan net kâr marjı oranı, 2018 ve 2019 yıllarında azalış, 2020 yılında artış göstermiştir. Net kâr marjındaki azalış; şirketlerin 2018 ve 2019 yıllarında net satışlarının sırasıyla; \%29,23 ve \%22,06 artmasına karşın dönem kârının \%-33,28 ve \%15,1 değişim göstermesinden kaynaklanmaktadır. 2020 yılında ise şirketlerin dönem kârının \%254,42 artmasına karşın net satışlarının \%32,01 artması, net kâr marjında olumlu bir artış etkisi yaratmıştır. Faaliyet kâr marjında ise 3 yılda da artış görülmektedir. Esas faaliyet kârındaki yüzdesel değişimlerin, 3 yılda da net satışlardaki değişimden fazla olması, bahsedilen artışı açıklamaktadır. Toplam borç / toplam varlıklar oranı incelendiğinde, örneklemin bütününe paralel olarak 2018 yılında azalış, 2019 yılında artış gözlemlenmiştir. 2020 yılında ise şirketlerin toplam borç / toplam varlıklar oranı örneklemin bütününe zıt hareket ederek azalma göstermiştir.

Tablo 8 ve Tablo 9'da TFRS 16'nın Elektrik, Gaz ve Su sektöründe faaliyet gösteren işletmelerin finansal durum tablosu ve gelir tablolarında yer alan, kiralama işlemlerinin etkilediği finansal tablo kalemlerinin tutarları, değişimleri ve finansal oranları sunulmuştur. 
Tablo 8: Elektrik, Gaz ve Su Sektöründe Faaliyet Gösteren Şirketlerin TMS 17 ve TFRS 16 Uyguladı̆̆ Dönemlerde Finansal Durum Tablosu ve Gelir Tablolarında Yer Alan Başlıca Finansal Tablo Kalemlerinin Tutarları ve Değişimleri

\begin{tabular}{|c|c|c|c|c|}
\hline & \multicolumn{2}{|c|}{ TMS 17} & \multicolumn{2}{|c|}{ TFRS 16} \\
\hline & 2017 & 2018 & 2019 & 2020 \\
\hline Dönem Kâr1 & 1.480 .148 .856 & 557.737 .189 & 1.121 .989 .789 & 1.466 .521 .474 \\
\hline $\begin{array}{l}\text { Dönem Kârında Bir Önceki Yıla } \\
\text { Göre Değișim (\%) }\end{array}$ & - & $-62,31$ & 101,16 & 30,71 \\
\hline $\begin{array}{l}\text { Finansman Gideri Öncesi Faaliyet } \\
\text { Kârı }\end{array}$ & 3.743 .742 .626 & 4.777.914.190 & 5.791 .239 .222 & 5.965 .651 .427 \\
\hline $\begin{array}{l}\text { Finansman Gideri Öncesi Faaliyet } \\
\text { Kârında Bir Önceki Yıla Göre } \\
\text { Değişim (\%) }\end{array}$ & - & 27,62 & 21,21 & 3,01 \\
\hline Esas Faaliyet Kârı & 3.213 .752 .357 & 4.741 .595 .267 & 5.608 .460 .367 & 5.736 .079 .963 \\
\hline $\begin{array}{l}\text { Esas Faaliyet Kârında Bir Önceki } \\
\text { Y1la Göre Değişim (\%) }\end{array}$ & 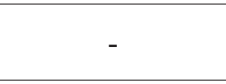 & 47,54 & 18,28 & 2,27 \\
\hline Faiz Gideri & 1.917 .985 .680 & 3.410 .012 .246 & 4.200 .172 .988 & 3.471 .950 .799 \\
\hline $\begin{array}{l}\text { Faiz Giderinde Bir Önceki Yıla } \\
\text { Göre Değişim }(\%)\end{array}$ & - & 77,79 & 23,17 & $-17,34$ \\
\hline $\begin{array}{l}\text { Kiralama İşlemlerinden Doğan } \\
\text { Faiz Gideri }\end{array}$ & & & 47.543 .262 & 39.665 .208 \\
\hline $\begin{array}{l}\text { Kiralama İşlemlerinden Doğan } \\
\text { Faiz Giderinde Bir Önceki Yıla } \\
\text { Göre Değişim (\%) }\end{array}$ & - & - & - & $-16,57$ \\
\hline Toplam Varlıklar & 37.694 .137 .521 & 49.913 .488 .030 & 54.280 .763 .595 & 60.220 .647 .195 \\
\hline $\begin{array}{l}\text { Toplam Varlıklarda Bir Önceki Yıla } \\
\text { Göre Değişim (\%) }\end{array}$ & 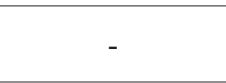 & 32,42 & 8,75 & 10,94 \\
\hline Toplam Yükümlülükler & 28.809 .818 .486 & 38.552 .157 .687 & 41.014 .975 .014 & 44.765 .753 .904 \\
\hline $\begin{array}{l}\text { Toplam Yükümlülüklerde Bir } \\
\text { Önceki Yıla Göre Değişim (\%) }\end{array}$ & 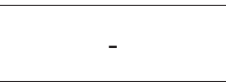 & 33,92 & 6,38 & 9,14 \\
\hline
\end{tabular}

Elektrik, gaz ve su sektöründe faaliyet gösteren işletmelerin başlıca finansal tablo kalemleri değerlendirildiğinde; dönem kârı kalemi hariç olmak üzere diğer kalemlerin örneklemin bütününe paralel olarak artış ve azalış gösterdiği saptanmıştır. Dönem kârı kaleminde 2018 yılında meydana gelen düşüşün en temel sebebi, Odaş şirketinin 2017 yılında 99.745.059 TL kâr açıklamasına karşın 2018 yılında -251.539.857 TL zarar açıklaması olarak belirtilebilir. Söz konusu şirketin brüt kârında esaslı bir düşüş olmamasına karşın faaliyetlerden kaynaklanan giderlerinin \%50 artması, şirketin böylesine büyük bir zarar açıklamasına sebep olmuştur. Dönem kârındaki düşüşün bir diğer sebebi olarak, sektörün en büyük şirketi olarak göze çarpan Enerjisa'nın, 2018 yılında 2017 yılına göre 240.312.000 TL daha az kâr etmesi söylenebilir. Söz konusu şirketin 2018 yılındaki brüt kârı, 2017 yılındaki brüt kârından \%50 fazla olmasına karşın şirketin vergi giderinin 278.590.000 TL artarak 2 katına çıkması, şirketin daha az kar etmesine sebep olmuştur. Elektrik, gaz ve su sektörünün en büyük şirketi olan Enerjisa'nın dönem kârındaki düşüş, doğal olarak sektörün dönem kârını da azaltmıştır. Öte yandan sektörün bir diğer büyük şirketi olan Aksa Enerji’nin brüt kârını neredeyse iki katına çıkarmış olmasına karşın 2017 yılında raporladığı yatırım faaliyetlerinden gelirler kalemini 2018 yılında raporlayamaması, şirketin bir önceki yıla göre daha az kâr etmesine sebep olmuş, bu durum da sektörün dönem kârının düşmesine sebep olmuştur. Dönem kârı kaleminde 2020 yılında meydana gelen artışın temel sebebi olarak, Zorlu şirketinin 2019 yılında 118.645 .000 zarar etmesine karşın 2020 yılında 34.548 .000 TL kâr açıklaması belirtilebilir. 
Tablo 9: Elektrik, Gaz ve Su Sektöründe Faaliyet Gösteren Şirketlerin TMS 17 ve TFRS 16 Uyguladığ1 Dönemlerdeki Finansal Oranları ve Değişimleri

\begin{tabular}{|l|c|c|c|c|}
\hline & \multicolumn{2}{|c|}{ TMS 17 } & \multicolumn{2}{c|}{ TFRS 16 } \\
\hline & $\mathbf{2 0 1 7}$ & $\mathbf{2 0 1 8}$ & $\mathbf{2 0 1 9}$ & 2,43 \\
\hline Aktif Kârlılık & 3,92 & 1,11 & 2,06 & 0,37 \\
\hline $\begin{array}{l}\text { Aktif Kârlılıkta Bir Önceki Yıla Göre } \\
\text { Değişim }\end{array}$ & - & $-2,81$ & 0,95 & 74,34 \\
\hline Toplam Borç / Toplam Varlıklar & 76,43 & 77,23 & 75,56 & $-1,22$ \\
\hline $\begin{array}{l}\text { Toplam Borç / Toplam Varlıklar } \\
\text { Oranında Bir Önceki Yıla Göre Değişim }\end{array}$ & - & 0,8 & $-1,67$ & 16,93 \\
\hline Net Kâr Marji & 28,79 & 6,76 & 14,09 & 2,84 \\
\hline $\begin{array}{l}\text { Net Kâr Marjinda Bir Önceki Yıla Göre } \\
\text { Değişim }\end{array}$ & - & $-22,03$ & 7,33 & 66,25 \\
\hline Faaliyet Kâr Marji & 62,53 & 57,48 & 70,41 & $-4,16$ \\
\hline $\begin{array}{l}\text { Faaliyet Kâr Marjinda Bir Önceki Yıla } \\
\text { Göre Değişim }\end{array}$ & - & $-5,05$ & 12,93 & \\
\hline
\end{tabular}

Elektrik, gaz ve su sektöründe yer alan işletmelerin finansal oranları incelenmiş ve söz konusu oranlarda meydana gelen artış ve azalışların örneklemin bütününe tamamen zıt olduğu görülmüştür. Tablo 14’te göze çarpan en önemli değişim, net kâr marjında 2018 yılında meydana gelen düşüştür. 2018 yılında şirketlerin dönem kârının \%62,31 düşmesine karşın toplam varlıklarının \%32,42 artması, bu düşüşü açıklamaktadır. Öte yandan göze çarpan bir diğer değişim, 2019 yılında faaliyet kâr marjının 12,93'lük artışıdır. Şirketlerin esas faaliyet kârının \%18,28 artmasına karşın net satışlarının \%3,45’lik bir düşüş göstermesi, faaliyet kâr marjındaki artışın sebebi olarak belirtilebilir.

Tablo 10 ve Tablo 11'de TFRS 16'nın Ulaştırma Haberleşme ve Depolama sektöründe faaliyet gösteren işletmelerin finansal durum tablosu ve gelir tablolarında yer alan, kiralama işlemlerinin etkilediği finansal tablo kalemlerinin tutarları, değişimleri ve finansal oranları sunulmuştur.

Tablo 10: Ulaştırma, Haberleşme ve Depolama Sektöründe Faaliyet Gösteren Şirketlerin TMS 17 ve TFRS 16 Uyguladığ Dönemlerde Finansal Durum Tablosu ve Gelir Tablolarında Yer Alan Başlıca Finansal Tablo Kalemlerinin Tutarları ve Değişimleri

\begin{tabular}{|c|c|c|c|c|}
\hline & \multicolumn{2}{|c|}{ TMS 17} & \multicolumn{2}{|c|}{ TFRS 16} \\
\hline & 2017 & 2018 & 2019 & 2020 \\
\hline Dönem Kârı & 4.255 .908 .817 & 5.182 .182 .625 & 11.522 .639 .118 & -138.138 .057 \\
\hline $\begin{array}{l}\text { Dönem Kârında Bir Önceki Yıla } \\
\text { Göre Değişim (\%) }\end{array}$ & - & 21,76 & 122,35 & $-101,19$ \\
\hline $\begin{array}{l}\text { Finansman Gideri Öncesi Faaliyet } \\
\text { Kâr1 }\end{array}$ & 12.225 .808 .157 & 18.596.982.866 & 20.640 .850 .597 & 13.273.220.212 \\
\hline $\begin{array}{l}\text { Finansman Gideri Öncesi Faaliyet } \\
\text { Kârında Bir Önceki Yıla Göre } \\
\text { Değişim (\%) }\end{array}$ & - & 52,11 & 11 & $-35,70$ \\
\hline Esas Faaliyet Kârı & 11.399 .810 .202 & 17.800 .788 .574 & 19.948.854.008 & 12.909 .074 .211 \\
\hline $\begin{array}{l}\text { Esas Faaliyet Kârında Bir Önceki } \\
\text { Y1la Göre Değişim (\%) }\end{array}$ & - & 56,15 & 12,07 & $-35,29$ \\
\hline Faiz Gideri & 1.786 .810 .577 & 3.199 .674 .331 & 5.187 .508 .388 & 5.828 .472 .531 \\
\hline $\begin{array}{l}\text { Faiz Giderinde Bir Önceki Yıla } \\
\text { Göre Değişim }(\%)\end{array}$ & - & 79,07 & 62,12 & 12,35 \\
\hline $\begin{array}{l}\text { Kiralama İşlemlerinden Doğan } \\
\text { Faiz Gideri }\end{array}$ & - & - & 2.235 .180 .275 & 2.401 .369 .214 \\
\hline $\begin{array}{l}\text { Kiralama İşlemlerinden Doğan } \\
\text { Faiz Giderinde Bir Önceki Yıla } \\
\text { Göre Değişim (\%) }\end{array}$ & - & - & - & 7,43 \\
\hline Toplam Varlıklar & 139.853 .738 .775 & 201.704 .673 .536 & 253.554 .582 .198 & 312.693 .585 .791 \\
\hline $\begin{array}{l}\text { Toplam Varlıklarda Bir Önceki } \\
\text { Y1la Göre Değişim (\%) }\end{array}$ & 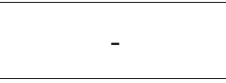 & 44,22 & 25,7 & 23,32 \\
\hline Toplam Yükümlülükler & 97.597 .925 .569 & 143.198 .068 .888 & 179.891 .615 .991 & 234.973 .854 .153 \\
\hline $\begin{array}{l}\text { Toplam Yükümlülüklerde Bir } \\
\text { Önceki Y1la Göre Değişim (\%) }\end{array}$ & - & 46,72 & 25,62 & 30,61 \\
\hline
\end{tabular}


Ulaştırma, haberleşme ve depolama sektöründe faaliyet gösteren şirketlerin finansal tablo kalemleri analiz edildiğinde; göze çarpan en büyük değişim 2020 yılında dönem kârında meydana gelen düşüştür. 2020 yılında dönem kârının, bir önceki yıla göre \%101,19 düşmesinin en temel sebebi, söz konusu sektörde havayolu şirketlerinin bulunmasıdır. Dünyanın birçok ülkesinde özellikle 2020 yılında etkisini gösteren Covid-19 salgınıyla birlikte yurt içi / yurt dışı uçuşların yasaklanması, havayolu şirketlerini fazlasıyla olumsuz etkilemiştir. Öyle ki sadece Türkiye’nin değil, dünyanın en büyük havayolu şirketlerinden biri olan Türk Hava Yolları'nın yolcu gelirleri \%60 düşmüş, pandemi sebebiyle artan kurla birlikte finansman giderleri \%238,26 artmıştır. Bu durum, THY'nin 2019 yılında 4.536.000.000 TL kâr ederken 2020 yılında 5.588.000.000 TL zarar etmesine sebep olmuştur. Öte yandan ulaştırma, haberleşme ve depolama sektöründe faaliyet gösteren bir diğer havayolu şirketi Pegasus'un yolcu gelirleri \% 56 düşmüş, uçak satış zararı ile birlikte yatırım faaliyetlerinden giderleri \%612,78 artmıştır. Bu durum Pegasus'un bir önceki y1l 1.334.567.915 TL kâr ederken 2020 yılında 1.965.097.057 zarar etmesine sebep olmuştur. Böylesine büyük iki şirketin dönem kârında meydana gelen bu büyük düşüşler, sektörün de dönem kârının şiddetli bir şekilde düşmesine sebep olmuştur. Esas faaliyet kârında ve finansman gideri öncesi faaliyet kârında meydana gelen düşüşlerin sebebi de dönem kârının düşüş sebebiyle aynıdır. Şirketlerin 2020 yılında raporladığg giderlerinin 2019 yılıyla benzer olmasına karşın satışlarında meydana gelen sert düşüş, esas faaliyet kârını ve finansman gideri öncesi faaliyet kârını da olumsuz etkilemiştir.

Tablo 11: Ulaştırma, Haberleşme ve Depolama Sektöründe Faaliyet Gösteren Şirketlerin TMS 17 ve TFRS 16 Uyguladığ Dönemlerdeki Finansal Oranları ve Değişimleri

\begin{tabular}{|c|c|c|c|c|}
\hline & \multicolumn{2}{|c|}{ TMS 17} & \multicolumn{2}{|c|}{ TFRS 16} \\
\hline & 2017 & 2018 & 2019 & 2020 \\
\hline Aktif Kârlılık & 3,04 & 2,57 & 4,54 & $-0,04$ \\
\hline $\begin{array}{l}\text { Aktif Kârlılıkta Bir Önceki Y1la Göre } \\
\text { Değişim }\end{array}$ & - & $-0,47$ & 1,97 & $-4,58$ \\
\hline Toplam Borç / Toplam Varlıklar & 69,78 & 70,99 & 70,94 & 75,14 \\
\hline $\begin{array}{l}\text { Toplam Borç / Toplam Varlıklar } \\
\text { Oranında Bir Önceki Yıla Göre Değişim }\end{array}$ & - & 1,21 & $-0,05$ & 4,2 \\
\hline Net Kâr Marj1 & 18,76 & 16,95 & 33,58 & $-0,06$ \\
\hline $\begin{array}{l}\text { Net Kâr Marjında Bir Önceki Yıla Göre } \\
\text { Değişim }\end{array}$ & - & $-1,81$ & 16,63 & $-33,64$ \\
\hline Faaliyet Kâr Marj1 & 50,28 & 58,21 & 58,13 & 56,82 \\
\hline $\begin{array}{l}\text { Faaliyet Kâr Marjında Bir Önceki Yıla } \\
\text { Göre Değişim }\end{array}$ & - & 7,93 & $-0,08$ & $-1,31$ \\
\hline
\end{tabular}

Ulaştırma, haberleşme ve depolama sektöründe faaliyet gösteren şirketlerin finansal oranları incelendiğinde; aktif kârlılık oranının 2019 yılında bir önceki yıla göre artış gösterdiği, 2020 yılında ise 2019 yılına göre sert bir düşüş gösterdiği saptanmıştır. 2019 yılında şirketlerin dönem kârının 2018 yılına göre \%122,35 artmasına karşın toplam varlıklarının \%25,70 artması, 2019 yılında meydana gelen artışı açıklar niteliktedir. Öte yandan 2020 yılında şirketlerin dönem kârının \%101,19 azalmasına karşın toplam varlıklarının \%23,32 artması, aktif kârlılık oranının 4,58 düşmesine sebep olmuştur. Benzer bir durum net kâr marjında da bulunmaktadır. 2019 yılında şirketlerin dönem kârının 2018 yılına göre \%122,35 artmasına karşın net satışlarının \%12,22 artması, net kâr marjının 16,63 artmasına sebep olmuştur. Faaliyet kâr marjında ise 2019 yılında 2018 yılına göre ufak bir düşüş görülmektedir. Net satışların \%12,22 artmasına karşın esas faaliyet kârının \%12,07 artması, bu düşüşü açıklamaktadır. 2020 yılında da meydana gelen düşüşün sebebi, 2019 yılında olduğu gibi net satışlarda meydana gelen yüzdesel değişimdir.

Tablo 12 ve Tablo 13'te TFRS 16'nın teknoloji sektöründe faaliyet gösteren işletmelerin finansal durum tablosu ve gelir tablolarında yer alan, kiralama işlemlerinin etkilediği finansal tablo kalemlerinin tutarları, değişimleri ve finansal oranları sunulmuştur. 


\begin{tabular}{|c|c|c|c|c|}
\hline & \multicolumn{2}{|c|}{ TMS 17} & \multicolumn{2}{|c|}{ TFRS 16} \\
\hline & 2017 & 2018 & 2019 & 2020 \\
\hline Dönem Kâr1 & 1.584 .926 .670 & 2.420 .031 .300 & 3.284 .377 .353 & 4.521 .321 .526 \\
\hline $\begin{array}{l}\text { Dönem Kârında Bir Önceki Yıla } \\
\text { Göre Değişim (\%) }\end{array}$ & - & 52,69 & 35,72 & 37,66 \\
\hline $\begin{array}{l}\text { Finansman Gideri Öncesi Faaliyet } \\
\text { Kârı }\end{array}$ & 1.598 .183 .506 & 2.332 .316 .829 & 3.304 .063 .197 & 5.611 .117 .684 \\
\hline $\begin{array}{l}\text { Finansman Gideri Öncesi Faaliyet } \\
\text { Kârında Bir Önceki Yıla Göre } \\
\text { Değişim (\%) }\end{array}$ & - & 45,93 & 41,66 & 69,82 \\
\hline Esas Faaliyet Kârı & 1.470 .727 .754 & 2.271 .968 .690 & 3.296 .291 .366 & 5.591 .156 .288 \\
\hline $\begin{array}{l}\text { Esas Faaliyet Kârında Bir Önceki } \\
\text { Yıla Göre Değişim (\%) }\end{array}$ & - & 54,48 & 45,09 & 69,61 \\
\hline Faiz Gideri & 358.636 .963 & 622.906 .541 & 714.017 .717 & 693.799 .181 \\
\hline $\begin{array}{l}\text { Faiz Giderinde Bir Önceki Y1la } \\
\text { Göre Değişim (\%) }\end{array}$ & 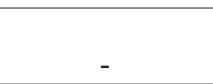 & 73,68 & 14,62 & $-2,83$ \\
\hline $\begin{array}{l}\text { Kiralama İşlemlerinden Doğan Faiz } \\
\text { Gideri }\end{array}$ & - & - & 10.432 .017 & 14.795 .262 \\
\hline $\begin{array}{l}\text { Kiralama İşlemlerinden Doğan Faiz } \\
\text { Giderinde Bir Önceki Yıla Göre } \\
\text { Değişim (\%) }\end{array}$ & - & - & - & 41,82 \\
\hline Toplam Varlıklar & 15.126 .289 .546 & 22.854 .388 .880 & 30.055 .972 .565 & 40.566 .696 .221 \\
\hline $\begin{array}{l}\text { Toplam Varlıklarda Bir Önceki Yıla } \\
\text { Göre Değişim (\%) }\end{array}$ & 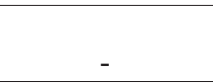 & 51,09 & 31,51 & 34,97 \\
\hline Toplam Yükümlülükler & 9.357 .094 .300 & 11.446 .108 .629 & 15.383 .056 .305 & 21.215 .891 .981 \\
\hline $\begin{array}{l}\text { Toplam Yükümlülüklerde Bir } \\
\text { Önceki Yıla Göre Değişim (\%) }\end{array}$ & - & 22,32 & 34,39 & 37,91 \\
\hline
\end{tabular}

Teknoloji sektöründe faaliyet gösteren işletmelerin başlıca finansal tablo kalemleri değerlendirildiğinde; dönem kârı kalemi hariç olmak üzere diğer kalemlerin örneklemin bütününe paralel olarak artış ve azalış gösterdiği saptanmıştır. Örneklemin bütününe zit olarak hareket eden 2020 yılının dönem kârında meydana gelen artışın en temel sebebi; 2020 yılında şirketlerin giderlerinin benzer olmasına karşın net satışlarının \%36, esas faaliyetlerinden diğer gelirler kaleminin \%79,14 artması olarak belirtilebilir. Esas faaliyetlerden diğer gelirler kaleminde meydana gelen böylesine büyük bir artışın kaynağı, şirketlerin faaliyetlerinden elde ettiği kur farkı gelirleridir. Öyle ki teknoloji sektörünün en büyük şirketi olan Teknosa, 2020 yılında 2019 yılına göre 3.310.403.000 TL daha fazla kur farkı geliri elde etmiştir. Yine teknoloji sektöründe faaliyet gösteren Indeks şirketi, 2020 yılında 2019 yılına göre 103.308.442 TL kur farkı geliri elde ederken Netaş, herhangi bir kur fark1 geliri elde etmemiştir. Öte yandan 2020 yılında şirketlerin esas faaliyet kârında ve finansman gideri öncesi faaliyet kârında meydana gelen artışın sebebi, dönem kârıyla aynıdır. Şirketlerin giderlerinin bir önceki yıla benzer olmasına karşın net satışlarının ve esas faaliyetlerinden diğer gelirler kaleminin artması, esas faaliyet kârını artırmış; bu durum da finansman gideri öncesi faaliyet kârına olumlu bir şekilde yansımıştır.

Tablo 13: Teknoloji Sektöründe Faaliyet Gösteren Şirketlerin TMS 17 ve TFRS 16 Uyguladı̆̆1 Dönemlerdeki Finansal Oranları ve Değişimleri

\begin{tabular}{|c|c|c|c|c|}
\hline & \multicolumn{2}{|c|}{ TMS 17} & \multicolumn{2}{|c|}{ TFRS 16} \\
\hline & 2017 & 2018 & 2019 & 2020 \\
\hline Aktif Kârlılık & 10,47 & 10,59 & 10,93 & 11,14 \\
\hline Aktif Kârlılıkta Bir Önceki Yıla Göre Değişim & - & 0,12 & 0,34 & 0,21 \\
\hline Toplam Borç / Toplam Varlıklar & 61,86 & 50,08 & 51,18 & 52,3 \\
\hline Toplam Borç / Toplam Varlıklar Oranında Bir Önceki Yıla Göre Değişim & - & $-11,78$ & 1,10 & 1,12 \\
\hline Net Kâr Marj1 & 86,85 & 96,02 & 86,44 & 87,49 \\
\hline Net Kâr Marjında Bir Önceki Yıla Göre Değişim & - & 9,17 & $-9,58$ & 1,05 \\
\hline Faaliyet Kâr Marj1 & 80,59 & 90,14 & 86,75 & 108,19 \\
\hline Faaliyet Kâr Marjında Bir Önceki Yıla Göre Değişim & - & 9,55 & $-3,39$ & 21,44 \\
\hline
\end{tabular}


Teknoloji sektöründe yer alan işletmelerin finansal oranları incelenmiş, toplam borç / toplam varlıklar ve faaliyet kâr marjı oranlarında meydana gelen artış ve azalışların örneklemin bütününe paralel olduğu görülmüştür. Öte yandan şirketlerin aktif kârlılık ve faaliyet kâr marjı oranlarında örneklemin bütününe zıt olarak sürekli artış gözlemlenmiştir. Şirketlerin dönem kârında meydana gelen artışların, 3 yılda da toplam varlıklarında meydana gelen artıştan fazla olması, aktif kârlılı̆̆ın sürekli artış göstermesine sebep olmuştur. Net kâr marjı incelendiğinde göze çarpan en önemli hususlar; 2018 yılında meydana gelen 9,17lik artış ve 2019 yılındaki 9,58'lik düşüştür. 2018 yılında şirketlerin bir önceki yıla göre dönem kârının \%52,69 artmasına karşın net satışlarının \%38,10 artması, dönem kârındaki 9,17’lik artışı açıklamaktadır. Öte yandan 2019 yılında şirketlerin bir önceki yıla göre dönem kârının \%35,72 artmasına karşın net satışların \%50,76 artması, net kâr marjında 9,58'lik düşüşe sebep olmuştur.

Tablo 14 ve Tablo 15’te TFRS 16'nın madencilik sektöründe faaliyet gösteren işletmelerin finansal durum tablosu ve gelir tablolarında yer alan, kiralama işlemlerinin etkilediği finansal tablo kalemlerinin tutarları, değişimleri ve finansal oranları sunulmuştur.

Tablo 14: Madencilik Sektöründe Faaliyet Gösteren Şirketlerin TMS 17 ve TFRS 16 Uyguladığı Dönemlerde Finansal Durum Tablosu ve Gelir Tablolarında Yer Alan Başlıca Finansal Tablo Kalemlerinin Tutarları ve Değişimleri

\begin{tabular}{|c|c|c|c|c|}
\hline & \multicolumn{2}{|c|}{ TMS 17} & \multicolumn{2}{|c|}{ TFRS 16} \\
\hline & 2017 & 2018 & 2019 & 2020 \\
\hline Dönem Kârı & 829.070 .000 & 1.870 .684 .000 & 2.969 .888 .000 & 2.872 .053 .000 \\
\hline $\begin{array}{l}\text { Dönem Kârında Bir Önceki Yıla } \\
\text { Göre Değişim (\%) }\end{array}$ & - & 125,63 & 58,76 & $-3,29$ \\
\hline $\begin{array}{l}\text { Finansman Gideri Öncesi Faaliyet } \\
\text { Kârı }\end{array}$ & 1.900 .451 .000 & 4.048 .754 .000 & 6.753 .408 .000 & 6.848 .108 .000 \\
\hline $\begin{array}{l}\text { Finansman Gideri Öncesi Faaliyet } \\
\text { Kârında Bir Önceki Yıla Göre } \\
\text { Değişim }(\%)\end{array}$ & - & 113,04 & 66,8 & 1,4 \\
\hline Esas Faaliyet Kârı & 1.208 .700 .000 & 2.231 .557 .000 & 4.775 .510 .000 & 4.924 .123 .000 \\
\hline $\begin{array}{l}\text { Esas Faaliyet Kârında Bir Önceki } \\
\text { Y1la Göre Değişim (\%) }\end{array}$ & - & 84,62 & 114 & 3,11 \\
\hline Faiz Gideri & 925.000 & 3.305 .000 & 3.948 .000 & 19.965 .000 \\
\hline $\begin{array}{l}\text { Faiz Giderinde Bir Önceki Yıla } \\
\text { Göre Değişim (\%) }\end{array}$ & - & 257,29 & 19,45 & 405,7 \\
\hline $\begin{array}{l}\text { Kiralama İşlemlerinden Doğan Faiz } \\
\text { Gideri }\end{array}$ & - & - & 3.479 .000 & 9.912 .000 \\
\hline $\begin{array}{l}\text { Kiralama İşlemlerinden Doğan Faiz } \\
\text { Giderinde Bir Önceki Yıla Göre } \\
\text { Değişim (\%) }\end{array}$ & - & - & - & 184,90 \\
\hline Toplam Varlıklar & 10.225 .546 .000 & 13.740 .825 .000 & 19.747 .603 .000 & 25.654 .066 .000 \\
\hline $\begin{array}{l}\text { Toplam Varlıklarda Bir Önceki Yıla } \\
\text { Göre Değişim (\%) }\end{array}$ & 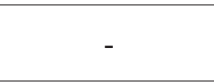 & 34,38 & 43,71 & 29,9 \\
\hline Toplam Yükümlülükler & 1.031 .244 .000 & 1.162 .975 .000 & 1.848 .356 .000 & 2.571 .844 .000 \\
\hline $\begin{array}{l}\text { Toplam Yükümlülüklerde Bir } \\
\text { Önceki Yıla Göre Değişim (\%) }\end{array}$ & - & 12,77 & 58,93 & 39,14 \\
\hline
\end{tabular}

Madencilik sektöründe faaliyet gösteren şirketlerin başlıca finansal tablo kalemleri incelenmiş ve 2020 yılında faiz giderinde meydana gelen artış hariç olmak üzere diğer kalemlerin örneklemin bütününe paralel olarak artış ve azalış gösterdiği saptanmıştır. Aynı zamanda 2020 yılında faiz giderinde meydana gelen bu artış, göze çarpan en önemli değişim olarak görülmektedir. Madencilik sektöründe yer alan şirketlerin finansal tablo dipnotları incelendiğinde, faiz giderindeki bu artışın kiralama yükümlülüklerinden doğan faiz giderinden oluştuğu görülmektedir. Öyle ki, 2019 yılında 3.479.000 TL bakiyesi bulunan "kiralama yükümlülüklerine ilişkin faiz gideri” kalemi, 2020 yılında \%184,90 artarak 9.912.000 TL'ye ulaşmıştır. Öte yandan 2018 yılında bir önceki yıla göre faiz giderinde gerçekleşen \%257,29 artış, İpek şirketinden kaynaklanmakta olup söz konusu şirketin finansal tablo dipnotlarında artan faiz giderine ilişkin bir açıklama bulunmamaktadır. Tablo 19'da göze çarpan bir diğer husus, 2018 yılında şirketlerin dönem kârında ve finansman gideri öncesi kârında gerçekleşen artıştır. Madencilik sektöründe bulunan şirketlerin 2018 yılında net satışlarının bir önceki yıla göre \%79,31 artmasına karşın giderlerinin \%70 ve satışlar dışında kalan gelirlerinin \%158,34 artması, dönem kârındaki bu 
artışın en temel sebebidir. Finansman gideri öncesi kârında meydana gelen artışın sebebi de dönem kârında gerçekleşen artışın sebebiyle aynıdır. Şirketlerin net satışlarının ve faaliyetlerden elde ettiği gelirlerin artış yüzdesinin, giderlerinin artış yüzdesinden çok fazla olması, finansman gideri öncesi faaliyet kârında artışa sebep olmuştur.

Tablo 15: Madencilik Sektöründe Faaliyet Gösteren Şirketlerin TMS 17 ve TFRS 16 Uyguladığı Dönemlerdeki Finansal Oranları ve Değişimleri

\begin{tabular}{|l|l|l|l|l|}
\hline & TMS 17 & \multicolumn{3}{l|}{ TFRS 16 } \\
\hline & $\mathbf{2 0 1 7}$ & $\mathbf{2 0 1 8}$ & $\mathbf{2 0 1 9}$ & $\mathbf{2 0 2 0}$ \\
\hline Aktif Kârlılık & 8,1 & 13,61 & 15,03 & 11,19 \\
\hline Aktif Kârlılıkta Bir Önceki Yıla Göre Değişim & - & 5,51 & 1,42 & $-3,84$ \\
\hline Toplam Borç / Toplam Varlıklar & 10,08 & 8,46 & 9,36 & 10,02 \\
\hline $\begin{array}{l}\text { Toplam Borç / Toplam Varlıklar Oranında Bir Önceki } \\
\text { Yila Göre Değişim }\end{array}$ & - & $-1,62$ & 0,9 & 0,66 \\
\hline Net Kâr Marji & 50,86 & 64 & 52,33 & 46,42 \\
\hline Net Kâr Marjinda Bir Önceki Yıla Göre Değişim & - & 13,14 & $-11,67$ & 5,91 \\
\hline Faaliyet Kâr Marji & 74,15 & 76,35 & 84,14 & 79,58 \\
\hline Faaliyet Kâr Marjında Bir Önceki Yıla Göre Değişim & - & 2,2 & 7,79 & $-4,56$ \\
\hline
\end{tabular}

Madencilik sektöründe yer alan şirketlerin finansal oranları analiz edildiğinde; aktif kârlılık oranının 2018 yılında bir önceki yıla göre artış gösterdiği, 2020 yılında ise 2019 yılına göre sert bir düşüş gösterdiği saptanmıştır. 2018 yılında şirketlerin dönem kârının 2017 yılına göre \%125,63 artmasına karşın toplam varlıklarının \%34,38 artması, 2018 yılında meydana gelen artışı açıklar niteliktedir. Öte yandan 2020 yılında şirketlerin dönem kârının \%3,29 azalmasına karşın toplam varlıklarının \%29,9 artması, aktif kârlılık oranının 3,84 düşmesine sebep olmuştur. Benzer bir durum net kâr marjında da bulunmaktadır. 2018 yılında şirketlerin dönem kârının 2017 yılına göre \%125,63 artmasına karşın net satışlarının \%79,31 artması, net kâr marjının artmasına sebep olmuştur. 2019 yılında ise bahsedilen durumun tam tersi gerçekleşmiştir. 2019 yılında şirketlerin dönem kârının 2017 yılına göre \%58,76 artmasına karşın net satışlarının \%94,16 artması, 2019 yılında meydana gelen düşüşü açıklar niteliktedir.

\subsection{Araştırmanın Sonucu}

Araştırmanın başlangıcında; mali kuruluşlar ve holdingler hariç olmak üzere BİST 100 endeksinde yer alan şirketlerin başlıca finansal tablo kalemleri ve finansal oranları yıl bazında incelenmiştir. Böylelikle hem eski kiralama standardına hem yeni kiralama standardına göre ilgili dönemdeki finansal tablo kalemleri ve finansal oranlardaki değişim gözlemlenmiştir. Yıl bazlı değişimlerin gösterildiği tablolardan yapılan çıkârımlar kullanılarak şirketlerin TMS 17 standardını uyguladığı 2017 - 2018 yıllarındaki başlıca finansal tablo kalemleri ve finansal oranları ile TFRS 16 standardını uyguladığı 2019 - 2020 yıllarındaki finansal tablo kalemleri ve finansal oranları değerlendirilmiştir. TFRS 16 standardının uygulanmaya başlandığı yıl olan 2019 yılından sonra örneklemde yer alan şirketlerin; dönem kârının \%26,39, finansman giderleri/gelirleri öncesi faaliyet kârının \%29,88, esas faaliyet kârının \%30,53, faiz giderlerinin \%87,49, toplam varlıklarının $\% 57,12$ ve toplam yükümlülüklerinin \%59,64 artış gösterdiği saptanmıştır.

TMS 17 standardında faaliyet kiralamaları sonucu ortaya çıkan kira giderlerinin TFRS 16 standardında şirketlerin gelir tablosunda yer almaması, TFRS 16 standardına göre faaliyet kiralamalarında kiralanan varlığa ilişkin varlık ve yükümlülük kaydedilmesi ve söz konusu varlıklara ilişkin amortisman gideri ve faiz giderinin raporlanması; esas faaliyet kârındaki ve faiz giderindeki artışın sebeplerinden biri olarak söylenebilir. Bahsedilen duruma paralel olarak finansman gideri öncesi faaliyet kârında da artış tespit edilmiştir.

Şirketlerin TMS 17 standardını uyguladığı 2017 - 2018 yıllarındaki finansal oranları ile TFRS 16 standardını uyguladığı 2019 - 2020 yıllarındaki finansal oranları incelendiğinde, net kâr marjında azalma gözlemlenmiştir. Örneklemde yer alan şirketlerin dönem kârının \%26,39 artmasına karşın net satışlarının \%29,69 artması, net kâr marjındaki azalışı açıklar niteliktedir. Finansal oranlardaki bir diğer azalış aktif kârlılık oranında görülmektedir. Örneklemde yer alan şirketlerin dönem kârının \%26,39 artmasına karşın, varlıklarının \%57,12 artması, aktif kârlılık oranındaki azalışı açıklamaktadır. Faaliyet kâr marjı incelendiğinde, söz konusu oranın artış gösterdiği gözlemlenmiştir. Yeni kiralama standardında faaliyet 
kiralamasına ilişkin kira giderlerinin göz önünde bulundurulmaması, esas faaliyet kârını artırmış ve söz konusu artış, faaliyet kâr marjında olumlu yönde bir artışa sebep olmuştur. Finansal oranlardan bir diğeri olan toplam borç / toplam varlıklar oranı da TFRS 16'nın kullanıldığı dönemlerde, TMS 17'nin kullanıldığı dönemlere göre \%1,03 artmıştır.

TFRS 16'nın etkisi sektörel bazda da analiz edilmiştir. BİST 100 endeksini oluşturan sektörlerden en fazla işletmeyi kapsayan imalat sektöründe faaliyet gösteren şirketlerin TMS 17 standardını uyguladığı 2017 - 2018 yıllarındaki başlıca finansal tablo kalemleri ve finansal oranları ile TFRS 16 standardını uyguladığı 2019 - 2020 yıllarındaki finansal tablo kalemleri ve finansal oranları değerlendirilmiştir. Değerlendirme sonucunda dönem kârının \%24,63, finansman giderleri/ gelirleri öncesi faaliyet kârının \%25,17 esas faaliyet kârının \%26,57, faiz giderlerinin \%92,03, toplam varlıklarının \%78,54 ve toplam yükümlülüklerinin \%85,78 artış gösterdiği saptanmıştır. İmalat sektörü, tüm örneklemle kıyaslandığında söz konusu sektörde faaliyet gösteren şirketlere ait başlıca finansal tablo kalemlerinin tüm örneklemdeki şirketlere ait finansal tablo kalemleriyle paralel olduğu görülmektedir. İmalat sektörünün finansal oranlarındaki değişim incelendiğinde toplam borç / toplam varlıklar oranının örneklemin bütününe paralel olarak artış gösterdiği; aktif kârlılık oranının ve net kâr marjının da yine örneklemin bütününe paralel olarak azalış gösterdiği gözlemlenmiştir. Fakat faaliyet kâr marjında örneklemin tamamından farklı olarak bir azalış bulunmaktadır. Bu durum, TFRS 16 standardının kullanılmasıyla birlikte imalat sektöründe esas faaliyet kârının \%26,57 artmasına karşın net satışların \%37 artmasından kaynaklanmaktadır.

Analiz edilen bir diğer sektör, toptan ve perakende ticaret, otel ve lokantalar sektörüdür. Söz konusu sektörde faaliyet gösteren şirketlerin finansal tablo kalemlerindeki ve finansal oranlarındaki değişimler, imalat sektöründe olduğu gibi TFRS 16 kullanılmaya başlanmadan önceki ve sonraki ikişer yıl olarak incelenmiştir. İnceleme sonucunda dönem kârında \%109,32, finansman gideri/geliri öncesi faaliyet kârında \%102,93, esas faaliyet kârında \%130,93, faiz giderinde \%160,87, toplam varlıklarda $\% 75,38$ ve toplam yükümlülüklerde $\% 79,25$ artış saptanmıştır. Bu sektörde yer alan şirketlerin belirtilen finansal tablo kalemlerinde görülen yüksek yüzdesel değişimlerin sebeplerinden biri olarak, şirketlerin çok yüksek seviyede kira faaliyetleri gerçekleştirdiği söylenebilir. TMS 17'de "kira gideri” olarak raporlanan faaliyet kiralaması işlemlerine ilişkin TFRS 16'da doğrudan kira gideri olarak raporlanmayı amortisman ve faiz gideri olarak raporlanması ve kiralanan varlıklara ilişkin finansal durum tablosunda varlık ve yükümlülük raporlanması, tüm finansal tablo kalemlerinin artmasına dayanak teşkil eden unsurlardan biridir. Öte yandan şirketlerin finansal oranları incelendiğinde, BíST 100'e paralel olarak toplam borç / toplam varlıklar oranın ve faaliyet kâr marjının arttığı gözlemlenmektedir. Buna karşın aktif kârlılık oranının ve net kâr marjının sektöre zıt işlemesinin nedeni, kâr tutarının \%109,32 artış göstermesinden kaynaklanmaktadır. Kâr tutarında meydana gelen artışın sebeplerinden biri olarak şirketlerin kira gideri raporlamaması söylenebilir.

Görüldüğü üzere bu sektörde yer alan şirketlerin başlıca finansal tablo kalemlerinde meydana gelen değişimler, diğer sektörlere göre çok daha yüksektir. Dolayısıyla toptan ve perakende ticaret, otel ve lokantalar sektörünün TFRS 16 standardından en çok etkilenen sektör olduğu söylenebilir. Ayrıca BİST 100 endeksinde işlem gören şirketlerin finansal tablolarında sunulan bağımsız denetçi raporlarında yer alan kilit denetim konuları incelendiğinde; TFRS 16 standardının kilit denetim konusunda yer aldığı sektörlerin başında bu sektörün gelmesi de yeni kiralama standardından en çok etkilenen sektörün bu sektör olduğuna işaret etmektedir. Tablo 16'da hangi sektörde kaç işletmenin bağımsız denetim raporunda TFRS 16 standardının yer aldığı gösterilmiştir.

Tablo 16: TFRS 16 Standardının Kilit Denetim Konusu Olarak Bağımsız Denetçi Raporunda Yer Aldığı Sektörler ve Sektörlere Ait Şirket Sayıları

\begin{tabular}{|c|c|c|c|}
\hline & 2019 & 2020 & Sektör Toplamı \\
\hline İmalat Sektörü & 3 & 0 & 3 \\
\hline Toptan ve Perakende Ticaret, Otel ve Lokantalar Sektörü & 6 & 3 & 9 \\
\hline Ulaştırma, Haberleşme ve Depolama Sektörü & 3 & 0 & 3 \\
\hline Eğitim, Sağlık, Spor ve Diğer Hizmetler Sektörü & 1 & 0 & 1 \\
\hline TOPLAM & 13 & 3 & 16 \\
\hline
\end{tabular}

Tablo 16’da görüldüğü üzere, 2019 yılında toptan ve perakende ticaret, otel ve lokantalar sektöründe faaliyet gösteren 6 şirketin kilit denetim konularında TFRS 16 standardının yer aldığı görülmektedir. Öte yandan yine 2019 yılında imalat sektöründe 3, ulaştırma haberleşme ve depolama sektöründe 3 ve eğitim, sağlık, spor ve diğer hizmetler sektöründe 1 
şirketin bağımsız denetçi raporunda yeni kiralama standardının yer aldığı tespit edilmiş̧ir. 2020 yılında ise sadece toptan ve perakende ticaret, otel ve lokantalar sektöründe yer alan 3 şirketin kilit denetim konularında TFRS 16'nın yer aldığ 1 saptanmış, diğer şirketlerin kilit denetim konularında yeni kiralama standardından söz edilmemiştir.

Elektrik, gaz ve su sektörü; BİST 100 endeksinde yer alan 5 şirketin faaliyet gösterdiği sektör olarak göze çarpmaktadır. Söz konusu sektörde faaliyet gösteren şirketler, diğer sektörlerde olduğu gibi standart bazlı ve ikişer yıl olarak bir arada değerlendirildiğinde dönem kârında \%27,01, finansman gideri/geliri öncesi faaliyet kârında \%37,96, esas faaliyet kârında $\% 42,60$, faiz giderinde $\% 43,99$, toplam varlıklarda $\% 30,69$ ve toplam yükümlülüklerde $\% 27,34$ artı̧ gözlemlenmiştir. Diğer sektörler gibi elektrik, gaz ve su sektörü de bu yönüyle örneklemin bütününe paralellik göstermektedir. Elektrik, gaz ve su sektörünün finansal oranlarındaki değişim incelendiğinde faaliyet kâr marjının örneklemin bütününe paralel olarak artış gösterdiği; aktif kârlılık oranının da yine örneklemin bütününe paralel olarak azalış gösterdiği gözlemlenmiştir. Öte yandan net kâr marjının, örnekleme zıt olarak artış gösterdiği görülmüştür. Bu durum, TFRS 16 standardının kullanılmasıyla birlikte elektrik, gaz ve su sektöründe dönem kârının \%27,01 artmasına karşın net satışların \%24,15 artmasıyla açıklanabilir.

İncelenen bir diğer sektör, ulaştırma, haberleşme ve depolama sektörüdür. Söz konusu sektörde yer alan şirketlerin finansal tablo kalemleri ve finansal oranları, önceki sektörlerle aynı şekilde değerlendirilmiş, 2017 - 2018 ve 2019 - 2020 yılları ayrı ayrı birer dönem olarak kabul edilmiştir. Diğer sektörlerde olduğu gibi; ulaştırma, haberleşme ve depolama sektöründe de başlıca finansal tablo kalemleri, örneklemin tamamına paralellik göstermiştir. Söz konusu sektörde faaliyet gösteren şirketlerin dönem kârının \%20,62, finansman gideri/geliri öncesi faaliyet kârının \%10,02 esas faaliyet kârının \%12,52, faiz giderinin $\% 120,91$, toplam varlıkların $\% 65,78$ ve toplam yükümlülüklerin $\% 72,28$ artması, bahsedilen paralelliği açıklamaktadır. Daha önce belirtildiği gibi TFRS 16 standardının kullanılmasıyla birlikte şirketler; faaliyet kiralamasına konu olan varlıklara ilişkin kira gideri raporlamayı terk etmiş, varlık ve yükümlülük raporlamaya başlamıştır. Bu durumla birlikte varlıklarda ve yükümlülüklerde artış olmuş, yükümlülüklerin artmasının bir sonucu olarak da faiz giderleri artış göstermiştir. Özetle; varlık, yükümlülük ve faiz gideri kalemlerinin artış göstermesinin sebeplerinden birinin kiralama işlemleri olduğu söylenebilir. Ulaştırma, haberleşme ve depolama sektörünün finansal oranlarındaki değişim değerlendirildiğinde toplam borç / toplam varlıklar oranının ve faaliyet kâr marjının örneklemin bütününe paralel olarak artış gösterdiği; aktif kârlılık oranının da yine örneklemin bütününe paralel olarak azalış gösterdiği gözlemlenmiştir. Öte yandan net kâr marjının, örnekleme zıt olarak artış gösterdiği görülmüştür. Bu durum, 2019 ve 2020 yıllarında Ulaştırma, haberleşme ve depolama sektöründe faaliyet gösteren şirketlerin dönem kârının \%20,62 artmasına karşın net satışlarının $\% 7,10$ artmasıyla açıklanabilir.

Başlıca finansal tablo kalemlerinin ve finansal oranlarının incelendiği bir diğer sektör teknoloji sektörüdür. Söz konusu sektörde yer alan şirketlerin başlıca finansal tablo kalemleri ve finansal oranları, TFRS 16 standardının kullanıldığı dönemlerde, TMS 17 standardının uygulandığı dönemlere göre artış göstermiştir. Söz konusu sektörde faaliyet gösteren işletmelerin başlıca finansal tablo kalemlerine ilişkin değişimler değerlendirildiğinde; dönem kârının \%94,9, finansman gideri/geliri öncesi faaliyet kârının \%126,82, esas faaliyet kârının \%137,46, faiz giderinin \%43,42, toplam varlıkların \%85,94 ve toplam yükümlülüklerin \%75,92 artı̧ gösterdiği tespit edilmiştir. Görüldüğü üzere teknoloji sektöründe yer alan şirketlerin finansal tablo kalemleri, örneklemin bütününe paralel olarak artı̧̧ göstermiştir. Öte yandan şirketlerin finansal oranları incelendiğinde aktif kârlılık oranının artış gösterdiği göze çarpmaktadır. 2019 ve 2020 yıllarında toplam varlıkların \%85,94 artmasına karşın dönem kârının \%94,90 artması bu durumu açıklar niteliktedir. Öte yandan faaliyet kâr marjının örneklemin bütününe paralel olarak artış gösterdiği; net kâr marjının da yine örneklemin bütününe paralel olarak azalış gösterdiği gözlemlenmiştir. Toplam borç / toplam varlıklar oranı ise örneklemin bütününün aksine, 2019 ve 2020 yıllarında azalmıştır.

Araştırmada analiz edilen son sektör ise madencilik sektörüdür. Söz konusu sektörde faaliyet gösteren şirketlerin finansal tablo kalemlerindeki ve finansal oranlarındaki değişimler, diğer sektörlerde olduğu gibi TFRS 16 kullanılmaya başlanmadan önceki ve sonraki ikişer yıl olarak incelenmiştir. İnceleme sonucunda 2019 ve 2020 yıllarında dönem kârının \%116,38, finansman gideri/geliri öncesi faaliyet kârının \%128,62, esas faaliyet kârının \%181,94, faiz giderinin \%465,34, toplam varlıkların \%89,43 ve toplam yükümlülüklerin \%101,44 artış gösterdiği tespit edilmiştir. Söz konusu kalemlerin hepsinde 
önemli artı̧̧ların görülmektedir. Ancak en önemli artı̧ olarak göze çarpan faiz giderindeki artışın temel sebebi olarak Koza Altın şirketinin TMS 17 kullandığı 2017 ve 2018 yıllarında kira gideri olarak raporladığı 33.805.000 TL gösterilebilir. Söz konusu rakamın, yükümlülük olarak kaydedilmesiyle birlikte faiz giderinde önemli bir artış meydana gelmiştir. Sektöre ait finansal oranlardan toplam borç / toplam varlıklar oranının ve faaliyet kâr marjının, örneklemin bütününe paralel olarak artış gösterdiği; net kâr marjının da yine örneklemin bütününe paralel olarak azalış gösterdiği gözlemlenmiştir. Öte yandan aktif kârlılık oranının örnekleme zıt olarak artış gösterdiği görülmüştür. Bu durum, TFRS 16 standardının kullanılmasıyla birlikte madencilik sektöründe dönem kârının \%116,38 artmasına karşın toplam varlıkların \%89,43 artmasıyla açıklanabilir. TFRS 16'nın finansal tablo kalemlerine ve finansal oranlara etkisi, Tablo 17 ve Tablo 18'de özet olarak belirtilmiştir:

Tablo 17: TFRS 16 Standardının Başlıca Finansal Tablo Kalemlerine Etkisi

\begin{tabular}{|c|c|c|c|c|c|c|}
\hline & $\begin{array}{l}\text { Dönem } \\
\text { Kârı }\end{array}$ & $\begin{array}{c}\text { Finansman } \\
\text { Gideri } \\
\text { Öncesi } \\
\text { Faaliyet } \\
\text { Kârı } \\
\end{array}$ & $\begin{array}{c}\text { Esas } \\
\text { Faaliyet } \\
\text { Kârı }\end{array}$ & $\begin{array}{l}\text { Faiz } \\
\text { Gideri }\end{array}$ & $\begin{array}{l}\text { Toplam } \\
\text { Varlıklar }\end{array}$ & $\begin{array}{c}\text { Toplam } \\
\text { Yükümlülükler }\end{array}$ \\
\hline BİST 100 & Artış & Artış & Artış & Artış & Artış & Artış \\
\hline İmalat Sektörü & Artış & Artış & Artış & Artış & Artış & Artış \\
\hline $\begin{array}{l}\text { Toptan ve Perakende Ticaret, Otel ve } \\
\text { Lokantalar Sektörü }\end{array}$ & Artış & Artış & Artış & Artış & Artış & Artış \\
\hline Elektrik, Gaz ve Su Sektörü & Artış & Artış & Artı̧̧ & Artış & Artış & Artış \\
\hline $\begin{array}{l}\text { Ulaştırma, Haberleşme ve Depolama } \\
\text { Sektörü }\end{array}$ & Artış & Artış & Artış & Artış & Artış & Artış \\
\hline Teknoloji Sektörü & Artış & Artış & Artış & Artış & Artış & Artış \\
\hline Madencilik Sektörü & Artış & Artış & Artış & Artış & Artış & Artış \\
\hline
\end{tabular}

Tablo 17'de görüldüğü üzere; yeni kiralama standardının kullanıldığı 2019 ve 2020 yıllarında başlıca finansal tablo kalemlerinin tamamı, TMS 17 standardının kullanıldığı 2017 ve 2018 yıllarına göre artış göstermiştir. TFRS 16 standardının uygulanmasıyla birlikte kiralanan varlıklara ilişkin varlık ve yükümlülük raporlaması, toplam varlıklar ve toplam yükümlülükler kalemlerinde artışın sebeplerinden biridir. Toplam yükümlülükler kaleminde meydana gelen artış da faiz gideri kaleminde artışa yol açmıştır. Öte yandan TMS 17 standardına göre faaliyet kiralamaları sonucunda ortaya çıkan kira giderlerinin yeni kiralama standardına göre şirketlerin gelir tablolarında yer almaması; finansman gideri öncesi faaliyet kârındaki artışa dayanak teşkil etmiş, bahsedilen artış da esas faaliyet kârındaki artışı tetiklemiştir.

Tablo 18: TFRS 16 Standardının Finansal Oranlara Etkisi

\begin{tabular}{|l|c|c|c|c|}
\hline & $\begin{array}{c}\text { Aktif } \\
\text { Kârlılık }\end{array}$ & $\begin{array}{c}\text { Toplam Borç / Toplam } \\
\text { Varlıklar }\end{array}$ & Net Kâr Marjı & Faaliyet Kâr Marjı \\
\hline BİST 100 & Azalış & Artış & Azalış & Artış \\
\hline İmalat Sektörü & Azalış & Artış & Azalış & Azalış \\
\hline $\begin{array}{l}\text { Toptan ve Perakende Ticaret, Otel ve } \\
\text { Lokantalar Sektörü }\end{array}$ & Artış & Artış & Artış & Artış \\
\hline Elektrik, Gaz ve Su Sektörü & Azalış & Azalış & Artış & Artış \\
\hline $\begin{array}{l}\text { Ulaştırma, Haberleşme ve Depolama } \\
\text { Sektörü }\end{array}$ & Azalış & Artış & Artış & Artış \\
\hline Teknoloji Sektörü & Artı̧s & Azalış & Azalış & Artış \\
\hline Madencilik Sektörü & Artış & Artı̧s & Azalış & Artış \\
\hline
\end{tabular}

Tablo 18'de TFRS 16 standardının finansal oranlara etkisi, TFRS 16 kullanılmaya başlanmadan önceki ve sonraki ikişer yıl olarak hem sektörel bazda hem örneklem bazında incelenmiştir. İnceleme sonucunda örneklemin bütününde aktif kârlılık ve net kâr marjı oranlarında; artış faaliyet kâr marjı ve toplam borç / toplam varlıklar oranının ise artış gösterdiği saptanmıştır. Dönem net kârının \%26,39 artmasına karşın toplam varlıkların \%57,12 artması, aktif kârlılık oranındaki düşüşü açıklamaktadır. Öte yandan net kâr marjı oranında da düşüş görülmektedir. BİST 100 endeksinde bulunan işletmenin dönem kârının \%26,39 artmasına karşın net satışlarının \%29,69 artması, net kâr marjının azalmasına sebep olmuştur. Şirketlerin faaliyet kâr marjı değerlendirildiğinde, söz konusu oranın artış gösterdiği saptanmıştır. TFRS 16 standardının kullanılmaya başlanmasıyla birlikte faaliyet kiralamasına ilişkin kira giderlerinin raporlanmaması, esas faaliyet kârını 
artırıcı unsurlardan biridir. Esas faaliyet kârında meydana gelen bu artış da faaliyet kâr marjında olumlu yönde bir artışa sebep olmuştur. Finansal oranlardan bir diğeri olan toplam borç / toplam varlıklar oranı ise TFRS 16'nın kullanıldı̆̆ı dönemlerde, TMS 17’nin kullanıldığ 1 dönemlere göre artış göstermiştir.

Finansal oranlarda sektörel bazda meydana gelen artış ve azalışların sebebi de finansal tablo kalemlerinin birbirleri arasındaki yüzdesel farklılıklardır. Örneğin toptan ve perakende ticaret, otel ve lokantalar sektöründe aktif kârlılık oranının artış göstermesi, dönem kârının yüzdesel olarak toplam varlıklardan daha fazla artış göstermesinden kaynaklanırken, net kâr marjında meydana gelen artış ise dönem kârında meydana gelen artışın net satışlardaki artıştan daha fazla olmasından kaynaklanmaktadır.

\section{Sonuç}

İşletmelerin faaliyetlerini gerçekleştirebilmek, büyümek ve rekabet avantajı sağlayabilmek adına ihtiyaç duydukları yüksek meblağlı varlıkları, satın almak yerine belirli kira ödemeleri karşılı̆̆ında kullanma hakkı veren kiralama işlemleri, 1950’li yıllarda ABD’de alternatif bir finansman yöntemi olarak ortaya çıkmıştır. 1960'lı yıllarda başta İngiltere olmak üzere gelişmiş Avrupa ülkelerine yayılan ve 1980'li yıllarda ülkemizde resmen tanınan ve uygulanmaya başlanan kiralama işlemleri, işletmeleri yüksek faizli banka kredilerinden veya kendi öz kaynaklarına başvurmaktan kurtarmış ve bu sebeple ortaya çıktığı andan itibaren hızla gelişim göstermiştir.

Özellikle son yıllarda önemi ve kullanımı oldukça artan kiralama işlemlerinin muhasebeleştirilmesi hususu, yıllar boyu tartışılan bir konu olarak literatürde yer almıştır. İşletmeler, 31 Aralık 2018 tarihinden önce TMS 17 standardını uygulamaktaydılar. Söz konusu standartta, faaliyet kiralaması işlemlerinde kiralanan varlıklara ilişkin varlık ve yükümlülüklerin finansal durum tablosu dişında bırakılmasından dolayı literatürde oldukça eleştiri alması sebebiyle Uluslararası Muhasebe Standartları Kurulu, UFRS 16 standardını hazırlamış ve söz konusu standart, KGK tarafından Türkçe'ye birebir çevrilerek TFRS 16 ismiyle yayımlanmıştır. TFRS 16, ülkemizde 31 Aralık 2018 tarihinden itibaren başlayan hesap dönemlerinde uygulanmak üzere 16 Nisan 2018 tarihinde yürürlüğe girmiştir. TFRS 16 standardıyla birlikte kiracı taraf için faaliyet kiralaması - finansal kiralama ayrımı sona ermiş, tüm kiralama işlemleri aynı şekilde muhasebeleştirilmeye başlanmıştır. Bu değişiklikle birlikte kiracı taraf, kiralama türü fark etmeksizin kiralama işlemlerine ilişkin varlık ve yükümlülük raporlamaya başlamıştır. Dolayısıyla şirketlerin finansal tabloları, daha şeffaf ve gerçeğe uygun hale gelmiştir.

Çalışmanın son bölümünde yeni kiralama standardının BİST 100 endeksinde faaliyet gösteren şirketlerin başlıca finansal tablo kalemlerine ve finansal oranlarına etkisi incelenmiştir. İnceleme sonucunda beklendiği üzere TFRS 16 standardının TMS 17 standardına göre başlıca finansal tablo kalemlerinin ve finansal oranların tümünde değişiklik yarattığı saptanmıştır. Söz konusu standardın kullanıldığg 2019 ve 2020 yıllarında şirketlerin başlıca finansal tablo kalemlerinin tümünde artış görülmüştür. Yeni kiralama standardının etkisi, sektörel bazda da değerlendirilmiş ve bu standarttan en çok Ulaştırma, Haberleşme ve Depolama sektörüyle Toptan ve Perakende Ticaret, Oteller ve Lokantalar sektörünün etkilendiği gözlemlenmiştir. Bu durum, şirketlerin bağımsız denetçi raporlarında yer alan kilit denetim konularına da yansımış; kilit denetim konularında TFRS 16 standardının yer aldığı şirketlerin çoğunun bahsedilen sektörlerde faaliyet gösterdiği saptanmıştır.

TFRS 16 standardının kullanılmaya başlanmasıyla birlikte şirketler, faaliyet kiralamasına konu olan varlıklarına ilişkin varlık ve yükümlülük raporlamaya başlamış ve bu sayede finansal tablolar daha şeffaf ve anlaşılabilir; finansal oranlar daha anlamlı hale gelmiştir. Ayrıca bu durum finansal tabloların gerçeğe uygun sunumunu güçlendirmiş ve muhasebe ilkelerinden “Tam Açıklama İlkesi” nin daha iyi uygulanmasını sağlamıştır.

Gelecek çalışmalarda, tüm BİST şirketlerinin finansal verileri kullanılarak çalışmanın örneklemi genişletilebilir. Öte yandan bu çalışmada; TFRS 16 standardının etkisi, TFRS 16 kullanılmaya başlanmadan önceki ve sonraki ikişer yıl baz alınarak analiz edilmiştir. Gelecek yıllarda yayımlanacak finansal tablolar kullanılarak dönem sayısı artırılabilir ve bu sayede TFRS 16'nın etkisi daha iyi analiz edilebilir. Ayrıca yurt dışında faaliyet gösteren halka açık şirketlerin finansal 
verileri ile Türkiye'de faaliyet gösteren şirketlerin finansal verileri karşılaştırılarak yeni kiralama standardının etkisi ülkeler bazında incelenebilir.

Hakem Değerlendirmesi: Dış bağımsız.

Çıkar Çatışması: Yazar çıkar çatışması bildirmemiştir

Etik Komite Onayı: Bu çalışma için etik komite onayı Arel Üniversitesi Etik Kurulu’ndan alınmıştır (Tarih:02.10.2020).

Finansal Destek: Yazar bu çalışma için finnansal destek almadığını beyan etmiştir.

Peer-review: Externally peer-reviewed.

Conflict of Interest: The author has no conflict of interest to declare.

Ethics Committee Approval: This study was approved by the Arel University Ethics Committee (Date:02.10.2020).

Grant Support: The author declared that this study has received no financial support.

\section{Kaynaklar}

Aktaş, R., Karğın, S. \& Arıcı, N.D. (2017). Yeni Kiralamalar Standardı UFRS 16'nın Getirdiği Yenilikler Ve İşletmelerin Finansal Tablolarına Ve Finansal Oranlarına Olası Etkilerinin Değerlendirilmesi. Journal of Business Research Turk, 9(4), 858-881.

Aslan, Ü. (2018). UFRS 16 kiralamalar standardı kapsamında faaliyet kiralamalarının kiracı işletme tarafından muhasebeleştirilmesi ve raporlanmas1. Muhasebe ve Finansman Dergisi, (77): 55-68

Ergül, N. ve Dumanoğlu, S. (2003). Finansal Kiralama, Der Yayınları, İstanbul.

Erol, A. (2011). Tüm Yönleriyle Finansal Kiralama (Leasing) Iç̧tihatlı \& Gerekçeli, Yaklaşım Yayıncılık, Ankara.

Finansal Kiralama, Faktoring ve Finansman Şirketleri Kanunu. (2012, 13 Aralık). Resmi Gazete (Sayı: 28496 (Mükerrer)). Erişim adresi: https://resmigazete.gov.tr/eskiler/2012/12/20121213-1.htm

Marşap, B. ve Yanık, S. (2018). IFRS 16 Kapsamında Kiralama İşlemlerinin Finansal Raporlamaya Etkisinin İncelenmesi. Muhasebe ve Finansman Dergisi, (80): 23-42

Öztürk, Can. (2016). UFRS 16 Kiralama İşlemleri Standardının Eski UMS 17 Standardı İle Karşılaştırılması Ve Almanya Ve Türkiye'de Hisse Senetleri Halka Açık Olan Hava Yolu Şirketlerinin Finansal Durumuna Etkisi. Muhasebe Bilim Dünyası Dergisi, (18): 1-50

Sarı, E. ve Güngör, N. (2020). TFRS 16 Standardının Seçilmiş BİST 100 Şirketlerinin Finansal Tabloları ve Finansal Performanslarına Etkisinin İncelenmesi. Anadolu Üniversitesi Sosyal Bilimler Dergisi, (3): 287-312

Serçemeli, M. \& Öztürk, M. (2016). Yeni Finansal Raporlama Standardı IFRS 16 Kiralama İşlemleri’nin Getirdiği Değişimler Üzerine Bir Değerlendirme. Mali Çözüm, (135): 31-48.

Şentürk, F. (2016). Türk Vergi Mevzuatı Kapsamında Faaliyet Kiralaması Yapan İşletmelerde Muhasebe Uygulamaları. Journal of Business Research, (8): 620-639

Toroslu, M.Vefa (1998). Leasing İşlemleri ve Muhasebesi, Etibank Yayınları, İstanbul.

Uygun, U. (2019). Yeni Kiralamalar Standardı TFRS 16'nın İsletmelerin Finansal Durumuna Etkileri; BİST Şirketleri Üzerine Bir Uygulama (Yüksek Lisans Tezi, Manisa Celal Bayar Üniversitesi, Manisa).

TFRS 16. Kiralamalar. Erişim adresi: https://www.kgk.gov.tr/Portalv2Uploads/files/Duyurular/v2/TFRS/TFRS_16.pdf

TMS 17. Kiralama İşlemleri. Erişim adresi: https://kgk.gov.tr/Portalv2Uploads/files/DynamicContentFiles/T\%C3\%BCrkiye\% $\%$ Muhasebe\%20Standartlar\%C4\%B1/TMSTFRS2011Seti/TMS17.pdf

BIST 100 Endeksi. (2020). Erişim adresi:

https://www.ekonomist.com.tr/encyclopedia/bist-100-endeksi

Leasing Nedir? Erişim adresi: https://www.qnbfl.com/leasing-nedir/ 